\title{
Supermanes modernos: utopía y crisis social en el nuevo vivir tzotzil en Chiapas, México*
}

\section{Modern supermen: utopia and social crisis in the new Tzotzil living in Chiapas, Mexico}

\author{
Isabel Neila Boyer** \\ Universidad Complutense de Madrid, Madrid, España \\ ISSN: ISSN-OI85-4259; e- ISSN: 2007-9I76 \\ DoI: http://dx.doi.org/10.28928/ri/752013/aot2/neilaboyeri
}

\section{Resumen}

Este texto analiza un fenómeno de conversión religiosa que ha pasado desapercibido en países donde el Ministerio Internacional Creciendo en Gracia tiene presencia. La acentuación de la utopía y el nulo interés por el reordenamiento de la existencia a partir de la modificación del cuerpo, el gestus y los hábitos personales propios de otros credos del cristianismo moderno lo distinguen, quizá motivando su invisibilidad académica. Empero, la vorágine de afiliaciones indígenas a ese ministerio deviene un hecho social privilegiado para entender, en el contexto de la"modernidad", la crisis de la sociedad tzotzil contemporánea y la persistencia del pensamiento escatológico maya asociado a una fuente de deseo de apropiación de la misma. Palabras clave: modernidad, milenarismo, conversión religiosa, Creciendo en Gracia (CEG), antropología de la salud

\footnotetext{
Abstract

Analysis of a phenomenon of religious conversion that has gone unnoticed in countries where the Growing in Grace sect is present. The emphasis of utopia and null interest in the rearrangement of existence from the modification of the body, gestus and personal habits of other faiths of modern Christianity distinguish it, perhaps motivating their academic invisibility. However, the vortex of indigenous affiliations to that ministry becomes a privileged social fact to understand, in the context of "modernity", the crisis of the contemporary Tzotzil society and the persistence of the Mayan eschatological thought associated to a strong desire of modernity's appropriation. Key words: modernity, millenarianism, religious conversion, Growing in Grace (CEG), anthropology of health
}

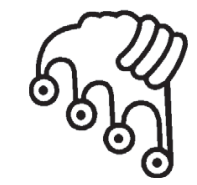

\section{IZTAPALAPA}

Agua sobre lajas

* El presente artículo es fruto del trabajo de campo ininterrumpido realizado en Los Altos de Chiapas entre los años 2006-2008 gracias al financiamiento de la Agencia Española de Cooperación Internacional para el Desarrollo (AECID) y al apoyo institucional $y$ humano del Centro de Investigaciones y Estudios Superiores en Antropología Social (CIESAS)-Sureste. Asimismo, todas las referencias a Creciendo en Gracia y su análisis se basan en la lectura de los 235 calqueos (sermones) que hasta el 21 de octubre de 2012 habían sido publicados en su web; 65 de ellos emitidos en 2009, 53 en 2010, 53 en 2011 y 64 en 2012.

** Departamento de Antropología Social y Cultural, Facultad de Filosofía, Universidad Nacional de Educación a Distancia (UNED) isabelnboyer@yahoo.com 


\section{La ruptura del mundo}

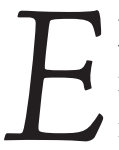

1 año 2012, más que nunca, y precisamente en esos momentos de crisis internacional del modelo de sociedad capitalista, los movimientos milenaristas y de la nueva era (o New Age) contribuyeron a estimular el interés general sobre los mayas, con base en la creencia escatológica de lo que se denominó fenómeno de 2012. Éste hacía referencia a que el día 21 de diciembre del mismo, en coincidencia con el solsticio, ocurriría el fin del mundo o se marcaría el inicio de un nuevo tiempo. Evidencias científicas sobre la actividad del universo más allá de la tierra y evaluaciones dogmáticas del deterioro político y social de la humanidad se conjugaron con percepciones y discursos globales de corte ecologista y catastrofista para inflar de contenido las interpretaciones sobre ciertas piezas arqueológicas y libros sagrados de los mayas, concretamente el Monumento Seis de Tortuguero y algún pasaje de los manuscritos Chilam Balam, que hacen referencia explícita al decimotercer baktun.

En un precioso e interesante trabajo de inicios de la década de los noventa, titulado "Alteridad étnica y conciencia moral. El Juicio Final de los mayas yucatecos”, Manuel Gutiérrez Estévez dedicaba un epígrafe a la descripción etnográfica de los prolegómenos del Juicio Final en el contexto de una concepción cíclica del tiempo, poniendo de relieve el sentido apocalíptico con que los mayas pensaban, y piensan, el tiempo presente. ${ }^{1}$ Ya en aquel entonces, advertía, estaban expectantes ante la inminencia del fin del mundo $y$, por tanto, de la segunda venida de Cristo. Algunos, afirmaba, auguraban que estos hechos se producirían en el año 2000, otros más eruditos sostenían que sería en el 2000 y pico; un pico sólo conocido por el mismo Dios. De cualquier forma, la cuenta del ciclo de los baktunes conducía a una fecha muy próxima a este año -como aquélla en que habría de comenzar un nuevo ciclo temporal-, fecha que conforme al calendario gregoriano sería el día 23 de diciembre de 2012 y momento escatológico anunciado en esta región maya por signos muy variados (Gutiérrez Estévez, 1992: 299-304).

1 Al respecto, véanse, por ejemplo, León-Portilla (1968), Farriss (1985), Reifler Bricker (1993), Gutiérrez Estévez (1992 y 1988). 
Sobre el tema, Gutiérrez Estévez comentaba que hacia 1920 recorrió gran parte de la península de Yucatán un hombre que se manifestaba públicamente como el profeta bíblico Enoc, cuyo recuerdo, a la fecha, es todavía vívido en muchos pueblos mayas. Al grado de que un testigo de dichas predicaciones le relató de la siguiente manera su mensaje:

El profeta dijo que vendría una hambre, vendría una guerra. Y el granizo [...] para acabar las bestias, gallinas, cochinos, todo, todo. Dijo él: ahí verán que vuelve a asomar la cometa grande que cubre medio cielo cuando sale. Esa cometa [Halley] salió el 1910 y este año que viene, el 1986, vuelve a salir. [...] Es un anuncio, son unas señas de que viene una vida más grave para nosotros: la carestía de la comida, el dinero no vale nada, ya no hay dinero. Es lo que viene para que nosotros vayamos ya terminando [Gutiérrez Estévez, 1992: 302].

Continuaba señalando cómo la terminación de este mundo se creía próxima debido a que las circunstancias anunciadas por Cristo para su segunda venida ya estaban cumplidas. La promesa evangélica: "la buena noticia del Reino se proclamará en el mundo entero para que llegue a oídos de todos los pueblos; entonces llegará el fin", era interpretada por algunos mayas yucatecos de una forma peculiar. Consideraban que, con aquellas palabras, Cristo aludía a la existencia del telégrafo, del ferrocarril y de una nueva carretera hasta Uxmal -lugar de ruinas mayas-, donde se haría justicia. En definitiva, la modernidad de las vías y medios de comunicación facilitarían el fin. Del siguiente modo le fue relatado por su informante, Plácido Poot, un hombre de Halachó:

Cuando vean que ya está empezando el anikab' [bejuco] -eso es maya, pero es "alambre"- donde hablan los ricos sobre leguas, ya está cerca el juicio. Cuando vean ustedes $x$-carretera-kak ["carretera de fuego"] -es el ferrocarril que está corriendo sobre leguas llevando gente- ya saben que ya está cerca mi segunda venida -cuenta que le dijo Jesucristo a San Pedro-. Y cuando ustedes vean un camino que van a hacer las autoridades -las autoridades lo van a hacer para negocio y no va a ser para negocio-, entonces mi Padre marcará para qué va a servir: para que corren todos hasta el fin del mundo a escuchar la justicia aquí, en las ruinas de Uxmal.

Con el milagro de Él vendremos a Uxmal para escuchar la justicia. Los que murieron cuando hizo el diluvio, ya están castigados; están durmiendo ahorita. Nosotros vamos a tener, a lo más, veinte años [estas palabras fueron dichas en 1981]. Somos los últimos, por eso hay que tomar el camino de Dios [Gutiérrez Estévez, 1992: 303-304]. 
Igualmente, algunos mayas tzotziles de la región de Los Altos de Chiapas -tal vez de forma más soterrada o menos explícita- comparten esta idea y, en su particular sincretismo y primacía de una concepción cíclica del tiempo (Farriss, 1985), conservan esa visión del mundo donde la sucesión de apocalipsis renueva periódicamente un pasado idílico que habrá de corromperse y degradarse hasta su extinción (Gossen, 1989 y 2002), no sin antes enviar señales de su fin. ${ }^{2}$ Pese a que pareciera que aquí han pasado desapercibidas las ideas del fin del mundo o de un fin de ciclo en el 2012 -y ahora ya en su contigüidad- y de la segunda venida de Cristo, no ha sido así. Aunque casi inadvertida hasta el momento para la academia -e incluso para los medios de comunicación-, los mayas tzotziles entraron en una nueva vorágine de conversión religiosa a un credo -hasta no hace mucho desconocido en la región- que articulaba en su discurso el mensaje mesiánico y milenarista: el Ministerio Internacional Creciendo en Gracia (CEG) ${ }^{3}$ Como suele ocurrir, esto ha sido así por la apreciación indígena compartida de una degradación de la vida, a la que difícilmente ahora pueden denominar buen vivir (lekil kuxlejal). Si bien los mayas yucatecos se apoyaban en signos como la hambruna generalizada, la muerte de los animales de granja a causa del granizo y el escaso valor del dinero para advertir el advenimiento de una vida "más grave" que sería el preludio del fin, los mayas tzotziles, aproximadamente desde mediados del siglo pasado, perciben la gravedad de su existencia como efecto de los múltiples cambios ocurridos en la región en aras de la "modernidad".

2 Los tzotziles (chamulas) han conservado a través de los siglos la idea de múltiples creaciones en donde el tiempo de ahora corresponde a la "cuarta creación": la última y más perfecta de las obradas por el Padre Sol (o "Nuestro Señor del Cielo"), equivalente a la figura de Jesucristo. Ésta es la única que ha tenido éxito, pero no es independiente de las anteriores, pues siguen un modelo de desarrollo acumulativo. Si las tres primeras resultaron en fracaso debido a que los humanos no congeniaban entre sí y tenían costumbres bárbaras, esta última -aunque exitosa- está repleta de maldad y corre el riesgo de volver a ser destruida. Para que esto no ocurra, hoy la gente se aplica en defenderla de la corrupción. Aún así, y debido precisamente a esa concepción cíclica del tiempo, el porvenir es acogido con pesimismo debido al pronóstico de su destrucción total alrededor del año 2000 (Gossen, 1989).

3 Frente a los centenares de entradas que surgen en cualquier buscador web sobre la conversión religiosa y la presencia de múltiples confesiones en Chiapas, y pese a su carácter internacional, los estudios académicos sobre el evangelismo CEG son nulos. Incluso, para la prensa regional, este fenómeno pasó desapercibido hasta el 26 de noviembre de 2012, fecha en que Cuarto Poder se hizo eco del asunto.

4 En otro trabajo (Neila Boyer, 2013), he analizado cómo, desde la irrupción de la llamada modernidad a las comunidades indígenas, se tiene la impresión de que la vida ha cambiado hacia un deterioro y el buen vivir, es cosa del pasado. Lo perciben así, entre otras cosas, por el arribo y hostigamiento de las que han denominado ach' chamel (nuevas enfermedades), cuyo origen compendian en las diferentes manifestaciones de la "modernidad" en su vida diaria: la construcción de mejores vías de comunicación hasta la adquisición de nuevos hábitos y la efervescencia de las interacciones sociales en un contexto ya desmedido y desbordado. En este sentido, por ejemplo, me decían: "Tenían buena vida anteriormente, pero ahora ya no es así; ahora ha cambiado la vida", o"Ya no es como antes. Los jóvenes antes se envejecían bien pero ahora ya no nos envejecemos. Muy joven nos morimos, ahora ya vivimos con enfermedad. La vida ya está cambiando". Para otras referencias, véase Jolom Mayaetik (2011). 


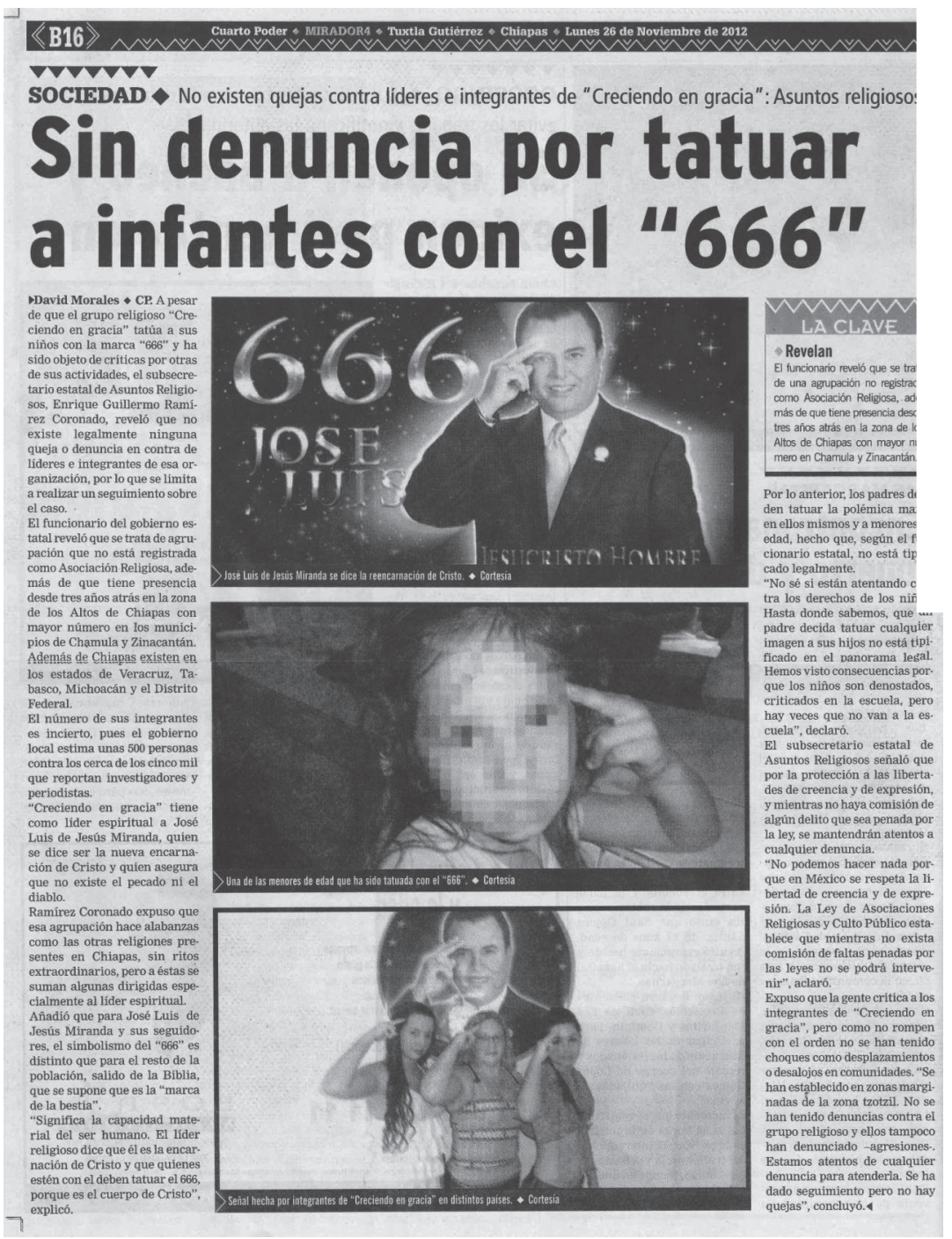

Fuente: Cuarto Poder, 26 de noviembre de 2012, p. B16. 
Desde que en los años sesenta México se convirtiera en protagonista de su propio despertar al crecimiento económico y a la "modernidad", lo que implicó profundas transformaciones socioculturales en todo el país, Chiapas-el estado más sureño de la nación- se vio inmerso en una vorágine transformadora de resultados todavía ambiguos para su elevado índice de población indígena. Si bien la llegada de la carretera panamericana a Los Altos supuso, desde 1950, la ruptura del aislamiento de esta región de refugio (Aguirre Beltrán, 1967) y su integración a una economía mercantil, fue hasta la década de los setenta cuando, gracias al boom petrolero, efectivamente, la sociedad agraria pasó a ser una imagen del ayer subdesarrollado iniciándose un proyecto modernizador, de consecuencias imprevisibles. Entre 1977 y 1981, durante los años de bonanza de la actividad petrolera nacional, coincidentes con momentos en que los controles sobre el precio del maíz y los elevados costes de los insumos necesarios para producirlo habían mermado la ganancia de los agricultores, el transvase de mano de obra indígena campesina hacia la construcción de diversas obras públicas -como las tres presas hidroeléctricas en la cuenca del río Grijalva (Collier, 1995)y la remodelación urbana de las ciudades fue significativo. ${ }^{5}$ Tanto, que además de la explotación petrolera, el creciente proceso de urbanización y la construcción de grandes obras de infraestructura, el desarrollo de las zonas turísticas, la expansión de la ganadería comercial y la industrialización contribuyeron a la intensificación y diversificación de la migración regional, nacional (a ciudades del centro y el norte del país) e internacional (a Estados Unidos). ${ }^{6}$ Todo ello trastocó la estructura demográfica y la realidad tradicional de las comunidades indígenas campesinas; éstas vivieron una serie de transformaciones que, aunadas a un ambicioso proyecto de desarrollo financiado por agencias internacionales, condujeron a la monetización de su economía, a la acumulación de capital y, por ende, a la ruptura de ese equilibrio idílico propio de las comunidades corporativas cerradas (Wolf, 1957 y 1986). La diferenciación económica y social entre sus miembros se convirtió en una realidad que ya no tendría vuelta atrás (Wasserstrom, 1980; Collier y Mountjoy, 1988; Cancian, 1992).

5 Para tener una idea de las dimensiones de este fenómeno, cabe advertir, por ejemplo, que hacia 1980 se habían creado alrededor de 17 mil nuevos empleos en la industria de la construcción en Chiapas (Rus y Collier, 2002).

6 Es justo advertir, como lo hiciera Wasserstrom (1980), que la realidad del campesinado indígena no se correspondía en absoluto, ni en estos momentos convulsos ni en décadas pasadas, con la imagen del agricultor autosuficiente de la mitología popular. Hacía mucho que las milpas habían dejado de ser rentables. Es más, el despojo a las comunidades indígenas de sus tierras comunales durante la segunda mitad del siglo XIX obligó a la población masculina a migrar estacionalmente a las empresas agrícolas capitalistas de otras regiones del estado, a las fincas cafetaleras en la región 
Asimismo, la vida política y cultural no quedó al margen. De forma paralela a los cambios en la estructura económica, y como efecto de las desigualdades generadas en el interior de las comunidades, a partir de la década de 1960 emergieron movimientos de oposición por el control de los cabildos, entonces en manos de una pequeña élite caciquil -fruto de la política indigenista posrevolucionaria impulsada en la región por el régimen cardenista- que había ido acumulando fortunas personales con el manejo de concesiones de transporte, el control de empleos en el magisterio y el acaparamiento de tierras comunales (Siverts, 1971; Rus, 1998). De esta manera, el poder tradicional -respetuoso con la costumbre y aliado de estructuras de gobierno para asegurar el control político de los pueblos- comenzó a ser cuestionado. Como si de un tornado que barre todo lo construido se tratara, empezó a evidenciarse en las comunidades un pluralismo religioso (alimentado por el cristianismo moderno) que después devendría en múltiples conflictos y expulsiones que habrían de mudar para siempre la estructura de estos pueblos y parajes, así como la fisionomía de la ciudad de San Cristóbal de Las Casas (Robledo Hernández y Cruz Burguete, 2005: 515-516).

Pero la convulsa década de 1970 dio paso a otra que estaría marcada en igual medida por el sino del cambio. Si antes éste quedaba justificado por el ímpetu del progreso y la supuesta modernidad, la profunda crisis económica de inicios de la década de 1980, en concreto en 1982, marcó una política gubernamental de ajuste y reestructuración (con miras al exterior), que se tradujo en el desmantelamiento del campo mexicano y chiapaneco $y$, por ende, en momentos nuevamente difíciles para la población indígena. La caída de los precios del maíz, que redundó en una disminución de la oferta de trabajo agrícola en la cuenca del río Grijalva; la paralización del empleo en la construcción debido a la regresión de la inversión estatal; la perspectiva truncada de recuperar el trabajo jornalero en las fincas cafetaleras del Soconusco como efecto de la afluencia de miles de centroamericanos que -tras huir de las guerras- se convirtieron en mano de obra más barata; y el acceso desigual a los productos químicos agrícolas - que acarreó el acaparamiento de la tierra en manos de campesinos acaudalados como efecto del endeudamiento de los más pobres (Rus y Collier, 2002)- profundizaron la creciente estratificación y polarización de las comunidades. Donde hasta hacía no mucho dominaban instituciones sociales de integración comunitaria-como el sistema de cargos cívicos y religiosos- basadas en la solidaridad social y la pobreza compartida, comenzó a evidenciarse un resquebrajamiento.

del Soconusco y el norte de Chiapas, a las monterías, donde se explotaba la madera en la Selva Lacandona, $y$ a los ranchos ganaderos y maiceros en los valles centrales. 
Esta situación de profundos cambios, vaivenes y vicisitudes que amenazaban a la sociedad indígena tradicional fue coronada, en el plano religioso, por la adopción del protestantismo por parte de amplios sectores indígenas pauperizados. De ahí que su emergencia y la consecuente fragmentación en nuevos grupos durante la década de 1980 representara las características de un "culto de crisis". El, por entonces, constante énfasis milenarista de su discurso -que preveía una vuelta a los orígenes como respuesta a una situación vital indeseada- sustentaba la creencia en el inminente fin del mundo en forma de hambrunas y el retorno de Cristo, para restablecer la armonía perdida apostaban por una renovación de la vida religiosa, política y sociocultural. Por otro lado, y como expresa Robledo Hernández, al tiempo que el protestantismo abrió espacio para un nuevo liderazgo indígena, también jugó "un papel de agente modernizador' de la comunidad tradicional al provocar la ruptura definitiva de las viejas estructuras comunitarias" (Robledo Hernández, 1997: 6-7).

Los efectos de esta vorágine transformadora han sido registrados por la población tzotzil bajo la categoría de nuevo vivir (ach’ kuxlejal). ${ }^{7}$ De este modo, aunque con más de tres décadas de diferencia, lo que con buen criterio han denominado la modernidad se ha convertido en el compendio de signos que bien pueden ser el agüero de que el fin de este mundo está próximo o, de igual manera, interpretarse como la toma de conciencia de que ya es presente otro tiempo. En definitiva, un nuevo vivir que, con base en la modificación progresiva de las pautas y cánones de la tradición y la costumbre, está sirviendo para pregonar, en diferentes formas, el final de una era o la disolución del mundo. Así, por ejemplo, en 1987, Maruch (María), la comadre de Diana Rus, le explicó en tzotzil: "Toj xokem xa li banamil, cumalee", es decir,"ya está roto el mundo" (Rus, 1990: 3). Una expresión que -como confesaba- no hizo más que reforzar su sensación acerca de los súbitos cambios que, en particular, estaban experimentando las

7 Hoy en día, en la región de Los Altos de Chiapas, el tiempo se clasifica en el "antes", o mas vóne ("antiguamente", "el tiempo pasado"), y el "nuevo vivir" con base, esencialmente, en cómo las personas establecen sus relaciones sociales y ordenan su experiencia vital. En el tiempo de antes -de manera general-, o entre quienes ahora apuestan por vivir como antaño, el principio que regula el modo de establecer las relaciones sociales y garantiza el correcto funcionamiento de la sociedad es el respeto. Éste significa el modo de proceder suave y con obediencia de quien contempla los consejos, de las personas manxas -el ideal de persona social por excelencia-, "cabales" o de "razón", y deviene del control sobre el cuerpo y las emociones, ejercido gracias a la "voluntad de la cabeza", que se forma a través del aprendizaje y la experiencia cultural. Todo ello da tersura a las interacciones sociales en tanto la tradición privilegia y valora la suavidad -que se refiere al equilibrio en todos los aspectos de la vida, a la par que es señal de la correcta sociabilidad y del buen vivir-, así como la templanza (tibieza), que significa sumisión, obediencia, humildad, contención emocional, mesura y armonía gestual. Para abundar sobre estos aspectos, véase Neila Boyer (2012a y 2013). 
vidas de las mujeres tzotziles, con quienes mantenía una relación de amistad. Pero esta frase, lejos de ser interpretada como un hecho aislado, tenía, para la antropóloga, resonancia con otras conversaciones que había sostenido. ${ }^{8}$ Pláticas -confesaba- que le hacían comparar su vida de entonces con la de hacía 17 años; es decir, la de mediados de los setenta. Concretamente María Gómez Pérez, Maruch, en el transcurso del relato de su existencia, ligada a la participación pionera en la constitución de un grupo de mujeres artesanas en la comunidad de K'at'ixtik, le dijo:"Todo está mal en la tierra de ahora, todo está roto. No es igual como antes” (Rus y Guzmán, 1990).

Desde entonces, la pretendida modernidad ha ido avanzando en esta dirección. Veinte años después, ya en el nuevo milenio, la idea de ruptura sin retorno se ha enraizado en el subconsciente colectivo y avivado, quizá, la necesidad de buscar -frente a un estado de crisis social- alivio, esperanzas y salvación en cultos de corte mesiánico y milenarista. ${ }^{9}$ Además, como bien expresaba López García (2006: 403), esta percepción de cambio irremediable, debilitante y anómico se ha enseñoreado en el cuerpo a modo de aflicción. Aunque aparentemente los tzotziles de Chiapas carecen de un discurso explícito sobre su fin -como el maya yucateco-, tienen, sin embargo, múltiples y variados relatos de vicisitudes que, al haber acontecido en esta "cuarta creación", bien pueden considerarse agoreras del mismo o, al menos, ilustrativas de la ruptura, destrucción o mal estado del mundo y la humanidad. ${ }^{10}$ Estas incidencias, en efecto, se han apropiado del

8 Decía ella: "Recordaba, por ejemplo, una [plática] con una comadre soltera quien no encontraba ninguna razón para casarse porque los hombres comían (y gastaban maíz) pero ya no podían mantener a sus familias; $u$ otra con una tejedora, sobre las niñas, que ya no aprendían los verdaderos trabajos de la mujer, de tejer e hilar, sino que la mayoría se habían convertido en 'ladinas' comprando su ropa para ir a la escuela; u otra con una comadre que vivía en San Cristóbal, quien ya se veía forzada a salir de su paraje a vender pulseras en las calles de esa ciudad porque no tenía dónde sembrar su milpa; u otra con el compadre que iba a buscar lugares en centros turísticos, como Palenque y Huatulco, donde su esposa podía vender sus artesanías y en donde él podía vender paletas [helados]" (Rus, 1990: 3).

9 Ya ha sido notada en otras ocasiones, y en otras geografías, cómo la transición brusca de un modelo social a otro -donde los subsistemas económico, social, político y cultural no han tenido tiempo para reconfigurarse equilibradamente y erosionado su capacidad de procurar satisfacción y felicidad- produce una estrecha relación con el milenarismo. Tal es el caso, por ejemplo, de la oleada milenarista de la Europa bajomedieval protocapitalista (Cohn, 1981 [1957]), o la renovación evangélica en Inglaterra y Estados Unidos durante la primera revolución industrial (Fukuyama, 1999).

10 Ya en 1989, Gossen apuntaba cómo la crónica de esta creación estaba construida con base en hechos marcados por la violencia de las guerras (de Independencia, la Guerra de Pedro Díaz Cuzcat, la Guerra de Pajarito, la Revolución Mexicana), las rebeliones, los movimientos nativistas, las catástrofes naturales (erupción del volcán Santa María), las enfermedades (epidemia de gripe de 1918) y la ruptura brusca de las tradiciones; crónica que, a la fecha, finalizaba con "El tiempo cuando se 
cuerpo indígena a modo de enfermedad y parecen no afectarles exclusivamente, sino que también consume a los animales domésticos, terminando con su vida. ${ }^{11}$

De este modo, ajenos en principio a la maraña discursiva sobre el advenimiento de un nuevo orden -o el final de éste- $y$, como veremos, más allá de la revitalización del sermón milenarista de algunos credos religiosos en momentos especiales de crisis -e incluso de los movimientos sociales y rebeliones de corte mesiánico (Reifler Bricker, 1993)-, los tzotziles contemporáneos están convencidos de que ahora es, al menos en parte, un nuevo tiempo, ach' kuxlejal; el cual se ha abierto paso progresivamente desde mediados del pasado siglo y dejado tras de sí indicios del futuro por venir, además de razones - más que potentespara esperar con ansias algún acontecimiento que augure una existencia más venturosa, aunque utópica. A partir de entonces, la estructura económica, religiosa y político-moral que sustentaba la tradición y la costumbre padece los embates de la pretendida modernidad y el capitalismo, con resultados estremecedores en el sentido más puro del término. Desde entonces también, como efecto de este cataclismo en do sostenido, se tiene la percepción de que las cosas han dejado de ser de forma paulatina como eran, para cambiar debido a la escolarización progresiva y la universalización de la educación, la migración nacional e internacional derivada -en principio- del cambio de modelo productivo, la irrupción de los medios de comunicación y la construcción y mejora de las vías de transporte, la diversificación de los credos religiosos, las interacciones cotidianas con el mundo mestizo - que no hacen sino estimular la ladinización de la vida cotidiana-,

construyó el camino a Tuxtla (yo-ra melcăh be ta tušta)", esto es, con la construcción de la sección de la carretera panamericana entre Tuxtla Gutiérrez, la capital del estado, y San Cristóbal de Las Casas. Concluía observando que "Los sucesos más recientes, desde 1950, todavía no se han cernido por la tradición para usarse como indicadores históricos generales. Una sequía de principios de la década de 1960, por ejemplo, puede llegar a ser un gran momento en la historia chamula, pero todavía no se puede saber al respecto con absoluta certeza. También es probable que la exploración petrolera de los años 1970 se recuerde como punto de referencia para la época contemporánea" (1989: 448-449). Al respecto, considerando las observaciones de Rus (1990) y Rus y Guzmán (1990), puedo intuir que, al menos en este último aspecto, ha sido así.

${ }^{11}$ En este sentido, varias mujeres me dijeron: "ya casi no tenemos pollos y no hay huevos. Ya no tenemos gallinas ponedoras, $y$ no es porque no las queramos consumir, es porque hay mucha enfermedad. Las gallinas se enferman, se mueren de tos"; "Las gallinas de rancho tampoco crecen -expresaba otra- y ya tenemos que comprar los huevos. Lo que pasa es que viene la peste. No sé a qué se debe. Si viene la peste nos roba todo, nos lleva todas las gallinas, mueren muchas. Se enferman de tos, diarrea, la caca ya se pone verde cuando el pollo se muere; o, si no, crecen granos en la cara, pero los granos bien hinchados y los ojos quedan bien hinchados". Otra observaba: "Ahora dicen de la existencia de muchas enfermedades; dicen que vienen de muy lejos las enfermedades, bueno, es lo que dicen, porque otras partes se inundan, en otros países, entonces en las corrientes de agua se distribuye. Ahí es donde encontramos las enfermedades. Mueren los caballos, mueren las vacas y otros animales; los suelos absorben y nosotros encontramos las enfermedades". 
el asociacionismo civil y su actividad basada en la defensa de derechos fundamentales, el cooperativismo femenino y cierta emancipación de las mujeres resultado de políticas indigenistas pasadas. Con todo ello $-y$ aunque parezca una observación maniquea-, otro perfil de humanidad, menos cabal, ha comenzado a dibujarse, ${ }^{12}$ aquellos a los que denominan los del nuevo crecimiento (ach' ch'ieletik) o los del nuevo vivir (ach' kuxlejaletik). El ethos y el gestus tradicionales -expresiones de la "voluntad de la cabeza"- han dado paso a la irreverencia y la exageración, que sustituyen los principios rectores del respeto y el comedimiento; la actuación a voluntad -agencia o "voluntad del corazón"; manifestación de una apertura emocional- esquina a la petición cordial como forma de establecer las relaciones humanas. ${ }^{13}$ Otra sociabilidad irrumpe en los escenarios cotidianos y ritualizados: más "abierta", más urgente, imperativa, desmesurada, inestable e impredecible; de interacciones y una movilidad epiléptica, sobreestimulada y abrumadoramente más compleja (Neila Boyer, 2012a). Con ella, las interacciones sociales se ponen a punto de ebullición, comprometen la estabilidad y provocan la disrupción social y la aflicción (Groark, 2005: 240-244; Neila Boyer, 2013). Aquí encuentran su debilidad -como estado social y físico-, su caldo de cultivo (Neila Boyer, 2013). Una debilidad que, como expondré, parece explicar la rápida expansión en Chiapas de Creciendo en Gracia.

Estas apreciaciones, como la tesis que defiende este artículo, son fruto de las observaciones y exégesis registradas durante dos años y medio de trabajo de campo en la región de Los Altos de Chiapas (2002, 2008 y 2009). Se basan, asimismo, en otro trabajo más amplio -objeto de mi tesis doctoral- donde se explicitan algunas cuestiones tan sólo apuntadas aquí de manera sucinta. No pretendo en estas páginas radiografiar el hecho social del aparente aumento de la conversión a Creciendo en Gracia sino, más bien, ofrecer una explicación de por qué esto puede ser así. De modo que el lector o lectora no encontrará en este texto un perfil del converso a este nuevo credo ni una descripción detallada acerca de sus peculiaridades en Chiapas; mucho menos datos estadísticos de todo cuanto pueda incumbir a este fenómeno. Es un hecho constatado la naturaleza efímera de las

${ }^{12}$ Para un análisis más profundo de esta dicotomía y sus implicaciones, véase Neila Boyer (2012a).

${ }^{13}$ La irrupción de la "modernidad" y el reacomodo a ella parecen haber provocado la inversión del protagonismo (y el contraste) de una voluntad regida por la razón -cerebro/cabeza- hacia (o frente a) otra gobernada por el corazón, $y$ entendida como efecto de la escolarización y el nuevo vivir. Hecho interpretado como un acercamiento a la identidad mestiza. Esta voluntad orientada por el corazón supone una mayor expresividad emocional y libertad personal, y equivale gestualmente -en términos de carácter- a la idea de sobrepasarse o excederse; gestos que son atribuidos a la pérdida del respeto por parte de las nuevas generaciones, quienes hacen lo que su corazón dice porque éste "es el que manda o es el quien piensa". La máxima expresión de esta pérdida del respeto es la práctica del noviazgo asociada a la opción por otro modo de vivir, o de querer construir la vida, con más agencia. Para abundar sobre estas cuestiones, véase Neila Boyer (2012a). 
adscripciones religiosas en esta región, o de las infidelidades indígenas (Pitarch, 2003) que parecen caracterizar la conversión religiosa en esta área cultural; de ahí que haya primado una aproximación de este tipo. Sí se encontrará, en cambio, la idea soterrada de que, tal vez, la afiliación a Creciendo en Gracia supone un nuevo modo emergente de consumir el producto religioso a través, precisamente, de su activa visibilidad en internet. Por ello, se ha priorizado un análisis de los postulados de esta religión a la luz de la realidad indígena tzotzil chiapaneca.

\section{El nuevo vivir y el ejército de Jesucristo Hombre ${ }^{14}$}

El 29 de septiembre de 2011, Carlos René de Jesús, colaborador de Creciendo en Gracia, daba testimonio del seminario en Chiapas con Jesucristo Hombre - encarnado por José Luis de Jesús Miranda, fundador y líder espiritual de CEG-. Hablaba entonces de la felicidad de un viaje que previó "precioso" y del espectáculo que supuso llegar a uno de los Centros Educativos CEG tras 12 horas de viaje. En un ejercicio de memoria -avivado por las imágenes del trayectocomentaba cómo tras 12 años de participar de este credo le emocionaba el cambio drástico que las comunidades indígenas de Chiapas habían experimentado desde que "la palabra" llegara a ellas. Asimismo, advertía cómo la superraza había aumentado en número, tamaño y sabiduría; tanto, que ahora costaba contarlos y existían nuevas generaciones formándose en sus postulados. ${ }^{15} \mathrm{Ob}$ servaba, además, cómo casi todos estaban ya tatuados con el 666 -incluso los bebés-, pues querían estar listos para el Armagedón. Este número -el 666 impreso como un sello en campañas colectivas de tatuaje promovidas por la organización, en las que trataban de "educar" sobre la misión de Jesucristo Hombre en la tierra y el sentido de la profecía apocalíptica que justificaba su segunda venida- era el "número del hombre", fuente de salud, sabiduría y prosperidad; no así el de la Bestia, el anticristo.

${ }^{14}$ En la redacción de este apartado tengo muy presente la obra de Barabas (1987).

${ }^{15}$ Según la filosofía de Creciendo en Gracia, las y los menores que han ido desarrollándose bajo su doctrina constituyen una superraza debido a que poseen conocimientos, sabiduría y entendimiento que los adultos no tienen. En las clases impartidas en los Centros Educativos CEG se les inculca que son dioses, ángeles, espíritus perfectos, que están completos y bendecidos. José Luis de Jesús Miranda afirma que "Son niños que nacen entre nosotros y no han pasado por las manos y la contaminación de las religiones actuales, por lo tanto ellos no tienen ese daño en sus mentes". Para una descripción más pormenorizada sobre ello, y los contenidos de adoctrinamiento desde 2009 hasta la actualidad, así como para visualizar un video de la superraza tzotzil en Chiapas, véase Creciendo en Gracia <http://www.telegracia.com/super-raza/> [24 de agosto de 2013]. 

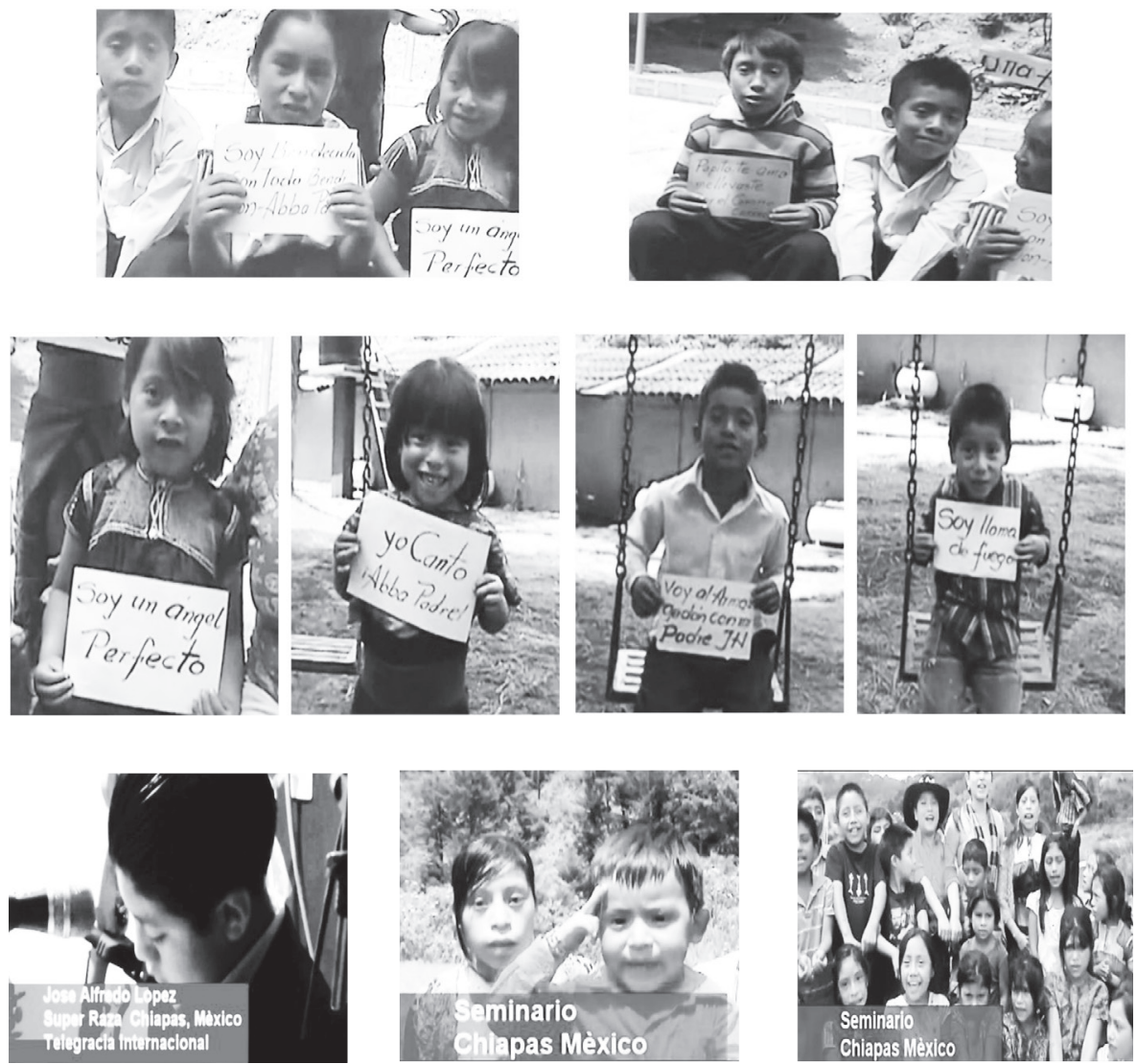

Fuente: Fotos extraídas del video Chiapas, México es de Jesucristo Hombre <http:www.youtube.com/ watch? $=9$ qw51HbXPEY> [24 de agosto de 2013]. Cuenta de YouTube asociada al video, cancelada.

El seminario que refiero se celebró durante la noche en Rancho San Carlos; lo recordaba así:

no cabe nadie. Se escucha la alabanza desde lejos. El ambiente es espectacular. A nuestro ingreso me dedico a contar las filas y su capacidad; apunto $y \ldots$ ¡ ¡Oh!, sorpresa, ¡hay más de dos mil bendecidos! Hay muchos de pie entre los espacios, en el centro, a los lados y atrás. El Centro Educativo perfectamente pintado con los colores de nuestra bandera. Foto gigantesca del Rey de Reyes. Alabanza en idioma propio de la región: ¡Se siente, se siente, José Luis está presente!

[...] no cabe ni una aguja y siguen llegando. Ya afuera del salón están congregados algunos, muchos. [...] Cuando llega el momento de la presentación de Jesucristo 

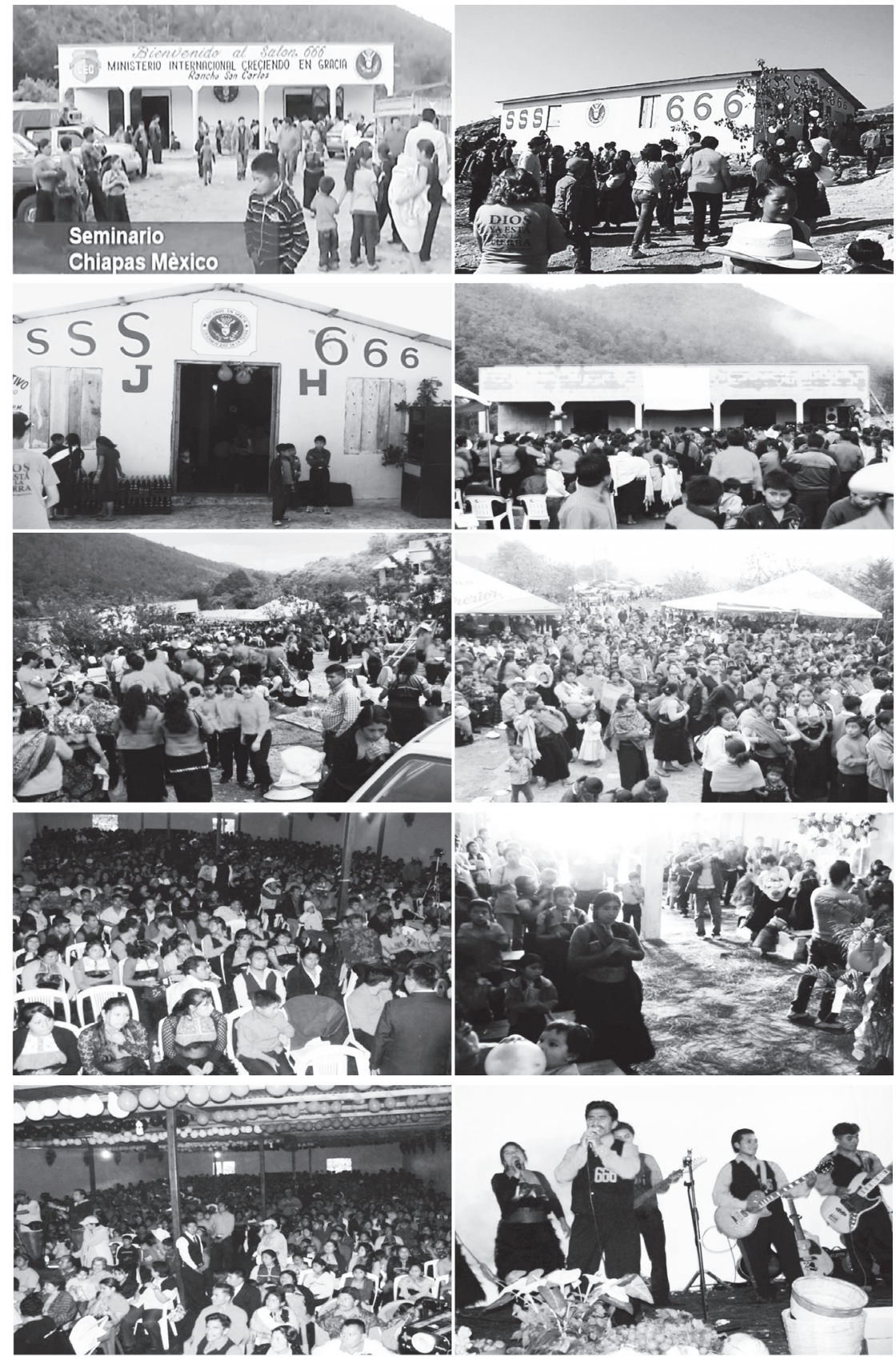

Fuente: Fotos extraídas del video Chiapas, México es de Jesucristo Hombre < http:www.youtube.com/watch?v $=9$ qw51HbXPEY $>$ [24 de agosto de 2013]. Cuenta de YouTube asociada al video, cancelada. 
Hombre irrumpen en aplausos, gritos de júbilo. Y no más que transportarse hasta donde aparece la imagen del Dios vivo... Silencio total. Dios va a hablarle a su pueblo; lo hará en español y utilizará la multiforme sabiduría y la omnipresencia. La pantalla es bastante grande, gigantesca diría yo; el audio es perfecto, se escucha hasta muchos metros fuera del local [...] Se inicia la conferencia. ¡Qué gloria! La atención es máxima; todos los ojos puestos en la pantalla y la mente puesta en Jesucristo Hombre.

Llega el domingo. [...] Camino al Centro Educativo el espectáculo se repite: cientos de bendecidos a bordo de vehículos, a pie o a caballo van llegando. El Centro Educativo nuevamente a full de capacidad. Ya cuando ha transcurrido la alabanza no cabe nadie: pasillos, entradas y exterior totalmente llenos. [... ] ni la intensa lluvia que caía impidió que el salón se llenara a su capacidad. El ánimo, el mejor; el gozo es evidente, una vez más fuimos edificados. [... [ La mente humana se pregunta: pero ¿hay más bendecidos por acá que se congregan?, y los miles que acabamos de ver ¿ya son bastantes o qué?

[...] Regresando por la carretera aún siento que estoy en las nubes. Suena la alabanza en mis oídos, en mi mente la imagen del Dios vivió. Todos se despidieron certeros en decir: "Hasta la transformación bendecido, nos vemos en Armagedón". Esas primicias están ciertas y sabidas de eso, acá no hay marcha atrás. Esos miles están contando los días rumbo a la transformación. [...] Muchos comentan que han soñado cómo va a ser, otros están con la curiosidad. Pero unos y otros tienen una mente firme y bien puesta su mirada en el autor y consumador. Están más firmes que nunca $y$ a la espera, en reposo y trabajando". ${ }^{16}$
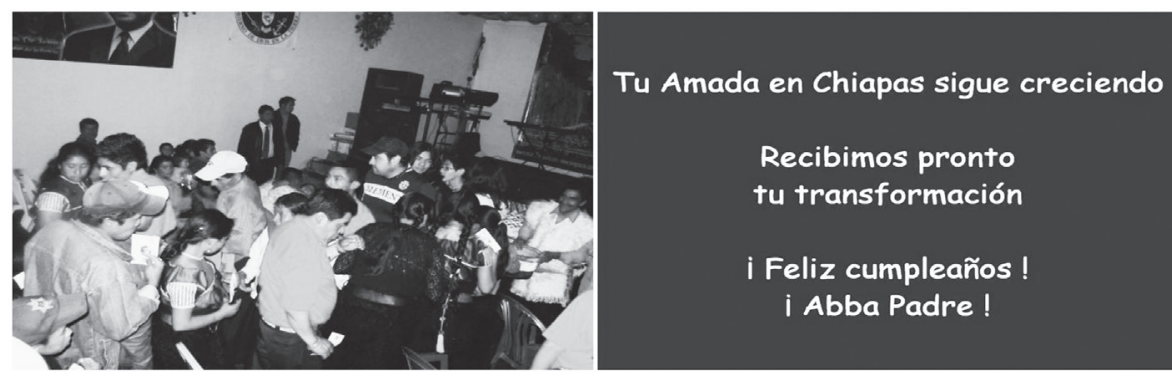

Fuente: Fotos extraídas del video Chiapas, México es de Jesucristo Hombre <http:www.youtube.com/ watch?v $=9$ qw51HbXPEY $>$ [24 de agosto de 2013]. Cuenta de YouTube asociada al video, cancelada.

${ }^{16}<$ http://www.telegracia.com/mitestimonio/2011/9/29/testimonio-del-seminario-con-jesucristohombre-en-chiapas-me.html> [agosto de 2012]. Testimonio eliminado de la web. 
Con la prudencia que inspiran las cifras exageradas y los puntos de vista interesados y dirigidos por anteojeras, es cierto que desde mi llegada a Chiapas -en septiembre de 2006-, hasta que estuviera por última vez allí en 2009, las referencias a Creciendo en Gracia han copado cada vez más los espacios de interacción reservados a la curiosidad y el anecdotario colectivo. De la misma manera que tales lugares verbales se han hecho espacio entre las noticias cotidianas de las comunidades indígenas, también los lugares físicos visibilizan cada día más su creciente presencia en la región: desde las instalaciones de la organización, que dan cuenta de su prosperidad allí, hasta las tienditas de abarrotes que flanquean la carretera y lucen, cual amuleto para la bonanza, el 666 en letras rotuladas. De cualquier modo, las informaciones llegaban a los municipios indígenas y sus parajes -como lo hacían todas-fragmentaria e imprecisamente y conferían potencia al gesto y significado del tatuaje del 666. Pero en 2008, esta fe comenzó a tener tal fuerza que los "bendecidos" empezaron a mostrar orgullosos sus brazos marcados con dicha cifra y la triple "s", en alusión a la frase "salvo, siempre salvo". Tanta era la satisfacción que incluso la vestimenta tradicional de cada comunidad, y las sonrisas, comenzaron a incorporar su iconografía en forma de coloridos bordados y dientes troquelados. Chiapas se convertía en un bastión CEG dentro del territorio nacional. ${ }^{17}$

En ese testimonio -y como final de ese ejercicio descriptivo y laudatorio-, Carlos René daba cuenta de lo gratificante y revelador que había sido su viaje aquí, no sólo por la oportunidad de presenciar la progresiva presencia de Creciendo en Gracia en la región, sino, además, por conocer in situ y desde su perspectiva -anclada en un imaginario nacional estereotipado- cómo "la palabra" había mejorado la vida miserable de los indígenas:

Me has privilegiado con muchos viajes, mi Dios, pero éstos a Chiapas en especial han sido edificantes... Hace doce años no tenían nada, quizás andaban descalzos y vivían muy mal, en condiciones infrahumanas, y tú los transformaste en sus mentes primero y luego en su manifestación económica. Les cambiaste sus rostros y refundaste esos pueblos. Están completos, no les hace falta nada y viven agradecidos con el que los salvó y se acordó de ellos. Les tendió su mano y los puso en pie a caminar

${ }^{17}$ Si bien Creciendo en Gracia ha irrumpido en un campo religioso local muy dividido y de variado espectro -cuyo perfil ha sido documentado-, cabe decir que, hasta la fecha de redacción de este artículo, no existen estimaciones oficiales ni aproximaciones académicas que ofrezcan el número de conversos, ya que es un fenómeno relativamente reciente y que ha pasado desapercibido. Aún así, y de ahí el valor de las imágenes anexas, es posible constatar su importancia con un vistazo a las fotografías ilustrativas del texto. 

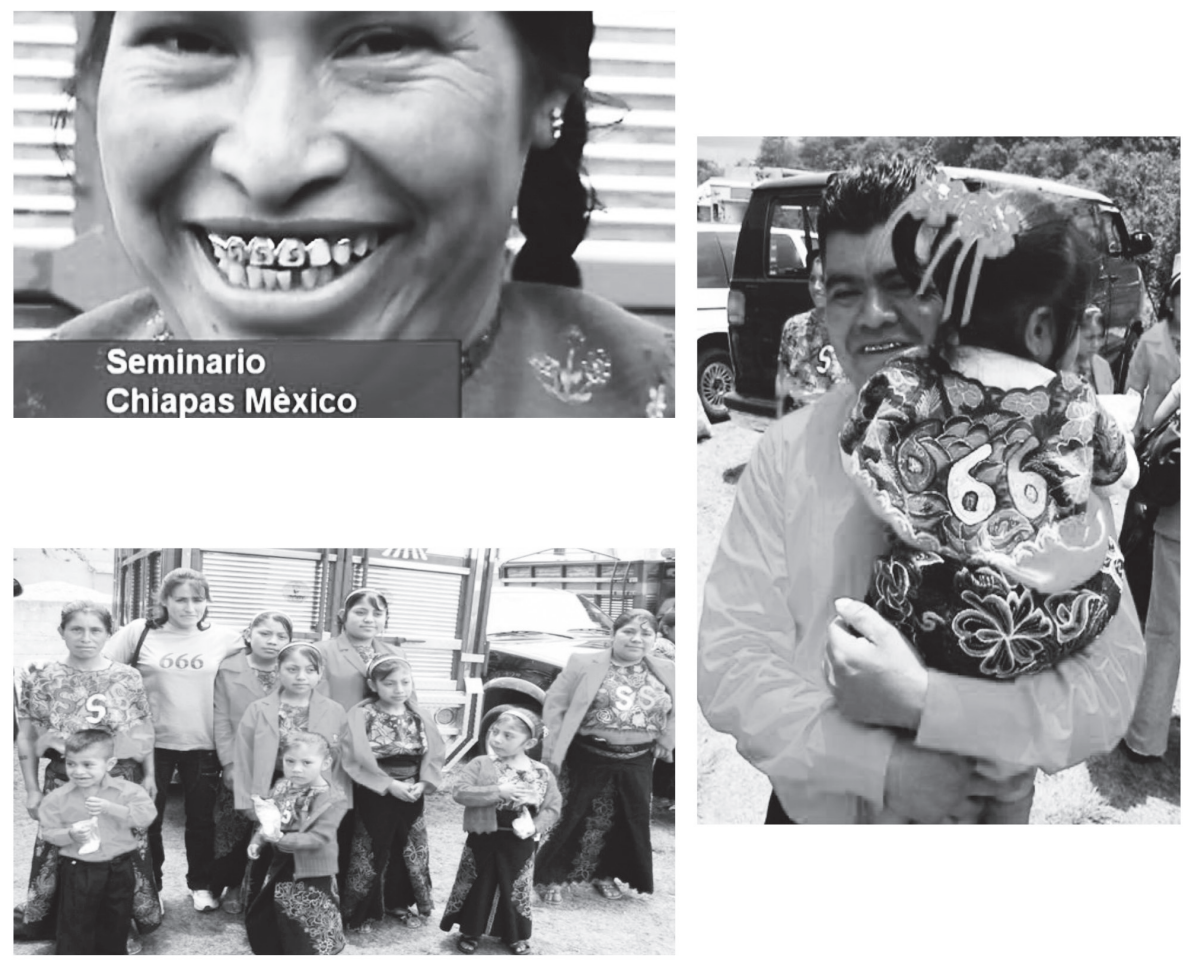

Fuente: Fotos extraídas del video Chiapas, México es de Jesucristo Hombre < http:www.youtube.com/watch?v =9qw51HbXPEY> [24 de agosto de 2013]. Cuenta de YouTube asociada al video, cancelada.

por la senda de la vida. Les enseñaste tantas cosas buenas. Los hiciste iguales no sólo entre ellos sino frente a los demás. Acá en Chiapas tienes un ejército que no se avergüenza de ti. ${ }^{18}$

Él apuntaba en su retórica todo cuanto Creciendo en Gracia podía brindar $y$, de hecho, a juzgar por la progresiva afiliación indígena, ofrecía: prosperidad, autoestima, plenitud, acompañamiento, agallas y brío ante la vida. En consecuencia, la pasión, la entrega, el júbilo, la atención, el ánimo y el gozo, la curiosidad y expectación con que fueron recibidos tenían que ver con las ideas y promesas de este credo acerca de su existencia como "seres completos", sin carencias ni necesidades, parejos entre sí y con el resto; como entes poderosos que han

18 <http://www.telegracia.com/mitestimonio/2011/9/29/testimonio-del-seminario-con-jesucristohombre-en-chiapas-me.html> [agosto de 2012]. Testimonio eliminado de la web. 
superado la debilidad y la aflicción gracias -como veremos más adelante- a la transformación de la mente y a la protección angelical tras la conversión, o que pueden llegar a serlo en el futuro, cuando ocurra la anunciada transformación corporal en el momento del Armagedón. En definitiva, el verdadero éxito de esta organización en Chiapas parecía provenir de la promesa de buenaventura en este mundo, no en el del más allá, gracias precisamente a esa metamorfosis del cuerpo y no a la salvación del alma. ${ }^{19}$ La creciente conversión a CEG parece constituir un intento de paliar el estado de debilidad social crónica impuesto por la "modernidad", que deviene del sobreesfuerzo cotidiano que hacen en los ámbitos productivo y emocional, todavía íntimamente imbricados en la estructura de las comunidades indígenas de la región (Neila Boyer, 2012b y 2013).

En este sentido, en numerosas ocasiones se ha advertido cómo, tras la emergencia, o éxito, de cualquier fenómeno milenarista, se encuentran gritos angustiados de cambio que emanan de motivos muy diversos y tras los que se oculta cierta frustración de las expectativas socioculturales y económico-políticas (Séguy, 1983; Desroche, 1973). Esto es un signo de la existencia de una crisis social producida como efecto de la desconexión o desfase entre las metas y expectativas vitales de las personas (culturales, subjetivas) y lo que les ofrece o puede ofrecerles el marco social en el que se desenvuelven sus vidas. Esta situación psicosocial genera frustración, insatisfacción, angustia, ansiedad e infelicidad, conduce a un fuerte deseo de cambio social (Desroche, 1973: 189) y abona la probabilidad de que una ideología utópica cuaje. Tanto así, que puede afirmarse que cualquier movimiento milenarista, como es el caso, constituye una especie de imagen distorsionada de la sociedad en crisis que lo ha despertado (Ullán de la Rosa, 2002: 71-72), al tiempo que promete una utopía social cuya sola esperanza en sí misma es un alivio.

Si bien es cierto que Los Altos de Chiapas han experimentado una serie de transformaciones que han supuesto una ligera mejoría -en el sentido de cierta apropiación de la "modernidad"-, ésta no ha terminado; en cambio, se perpetúan

${ }^{19}$ En un calqueo del 29 de junio de 2011 titulado "Resurrección versus transformación”, José Luis de Jesús Miranda -como encarnación de Cristo en su segunda venida- se desmarca de la resurrección, afirmando que si bien Jesucristo resucitó para mostrar su triunfo sobre la muerte, a sus seguidores les espera algo más perfecto que la resurrección de la carne. Advierte que él no puede "casar" a su Iglesia con un Cristo de carne que no tiene un cuerpo excelente e incorruptible. Y dice así: "entonces a la Iglesia la van a vestir de cuerpos incorruptibles, cuerpos de fuego, cuerpos radioactivos, cuerpos poderosos. Eso es lo que le espera a la Iglesia en la gloriosa transformación, ya no es resurrección es transformación. [...] lo que esperan los creyentes por ahí, los que nos critican a nosotros de falsos, ellos esperan una resurrección de carne y sangre, nosotros entendemos que hay un camino más excelente y es el ropaje divino, radioactivo, poderoso que nos espera para poder ser seres eternos y para siempre". 
los males del pasado con la posición de subalternidad, explotación y pobreza malintencionada. La realidad cotidiana se empecina en demostrar, de manera reiterada, que su asimilación ha resultado insuficiente para mejorar las condiciones de vida. Más aún, cuando se han logrado aparentes mejores condiciones de vida, ello ha contribuido a generar una sensación de insatisfacción, tanto de carácter material como en cuanto a metas y expectativas vitales se refiere. En esto se puede apreciar la estrecha relación entre este fenómeno y las precarias condiciones materiales de la existencia (Cohn, 1981 [1957]), pero, a diferencia de otras confesiones -especialmente las protestantes-, los principios de Creciendo en Gracia no van encaminados a un reordenamiento de la existencia a partir de la modificación o eliminación de los aspectos cotidianos más problemáticos, de los hábitos y las conductas disruptivas que redundan en la pobreza; es decir, no contemplan otra reglamentación de la vida, sino, más bien —y como veremos- la apropiación de los principios de Ceg desde la perspectiva del agente empoderado. Ofrece la utopía de una nueva sociedad de perfección ideal que sustituya al orden corrupto establecido; un mundo perfecto con una nueva humanidad, distinta de la actual, que habrá de constituirse tras el cataclismo apocalíptico.

Por otro lado, en este tiempo de nuevo vivir, los antiguos valores y expectativas que daban sentido a la existencia han dejado de ser referencia, mientras que aquellos introducidos por la "modernidad", difícilmente pueden ser satisfechos dada la situación marginal que ocupan dentro de la estructura social. ${ }^{20}$ Además, "los del nuevo vivir" o "los del nuevo crecimiento" introdujeron principios y maneras de estar-en-el-mundo, de entablar lazos interpersonales, basados en las emociones -más cercanos al mundo mestizo y a la apertura emocional que lo caracteriza-; alimentaron, también, nuevas ilusiones de vida más acordes con una realidad globalizada. ${ }^{21}$ Pero aunque esto sea así, además de encontrar sus

${ }^{20}$ Salvando las particularidades histórico-culturales, similar al panorama tzotzil y a la conversión a CEG es el presentado por Ullán de la Rosa (2002) entre la población nahua de la Huasteca mexicana y la afiliación al movimiento mesiánico Amalia Bautista.

${ }^{21}$ Tal manera de proceder equivale a actuar a la fuerza, "perder el respeto"; parece significar el abandono de la persona a la "voluntad del corazón" que impele hacia hábitos de kaxlanes (mestizos) y hacia una estética más moderna, asociada con la identidad mestiza. Los del nuevo crecimiento o los del nuevo vivir son, por lo general y debido a su actitud rebelde y emocional, tildados de toj jtoy ba (demasiado arrogantes, altivos, prepotentes y soberbios), chuvaj (locos) o simarrones (cimarrones). De ellos se dice que no obedecen y se extralimitan; aspectos sintomáticos de poseer un carácter fuerte que es notado como toj tzozt yo'on (demasiado fuerte su corazón), o toj tzozt chichel (demasiado fuerte su sangre). Esta actitud se trasluce en un gestus corporal exagerado: gesticulación excesiva, agresividad verbal, coquetería, entre otros. En este sentido, la aspereza propia de la "modernidad" está vinculada a la exageración y el desequilibrio del carácter, que conducen a 
valores cada día más influidos por el individualismo occidental, al mismo tiempo se hallan constreñidos por una vida tradicional aún corporativa en muchos aspectos. Al grado de que el relevo generacional ha dado paso a una generación aculturada que se siente atrapada en un contexto con el que ya no se identifica plenamente. Esta generación vive con intensidad las contradicciones suscitadas por el desfase entre la estructura social y el cambio cultural acelerado; entre lo que quieren ser y lo que el medio social les permite ser. Asimismo, aquellos que pretenden vivir conforme al orden tradicional, apegados a la costumbre, tienen que hacer frente a una realidad cotidiana donde imperan las fisiones intra- $\mathrm{e}$ interfamiliares, aquejando la mala unión de sus miembros y reconociendo que ahora la gente ya no está "bien unida", tzobolik lek (Groark, 2005: 243). No es extraño, pues, que en este contexto socialmente anómico broten cultos como Creciendo en Gracia (Pereira de Queiroz, 1977).

Todo ello perfila un panorama de grave crisis social y desorientación cultural e identitaria, donde al vértigo, la debilidad y los conflictos de identidad se une una retahíla de síntomas asociados. En este escenario, la población tzotzil se percibe a sí misma como atascada en medio del camino: sin poder dar marcha atrás y volver a ser lo que era y sin opción de asimilarse o semejarse -en ciertos aspectos- a la realidad nacional. Por ello, teniendo en cuenta lo sustancial del sistema social de valores para conferir sentido a la vida de las personas, resulta evidente cómo la confrontación entre los principios que ordenan la experiencia en el nuevo vivir y aquellos asentados en la costumbre produce el terreno idóneo para que acontezcan fenómenos de este tipo. Así, frente al vértigo y la desorientación cultural ante dos órdenes (el mestizo y el indígena) antagónicos, con la agotadora dinámica de las identidades múltiples y la renuncia parcial de la identidad social o étnica, emerge cierta necesidad de seguridad o esperanza buscada en ese mundo perfecto, ofrecido por los movimientos milenaristas (Burridge, 1969: 97-169). Además, no cabe duda de que en este caso -tal y como ponía de manifiesto Carlos René en su testimonio- la conversión a Creciendo en Gracia permite a la población tzotzil la recuperación de la autoestima frente al estado desmoralizador que imprime la supuesta modernidad. La conciencia de pertenecer a un grupo de elegidos alivia, en cierto sentido, ese sentimiento de desestructuración del antiguo orden social, de ruptura del mundo (Bastide, 1975: 154-160).

Por lo anterior -sin rechazar la interpretación de que en el pasado la afiliación al protestantismo respondía a un "culto de crisis" (Robledo Hernández, 1997),

comportamientos antisociales y dan lugar a una sociedad desigual, intratable y abrupta que, como efecto de las fricciones, redunda en un sentimiento de debilidad generalizada. Para abundar sobre estos aspectos, véase Neila Boyer (2012a y 2013). 
y de que la emergencia de movimientos de corte mesiánico en la región (Reifler Bricker, 1993) fuera resultado (desde un enfoque marxista: Balandier, 1955 y Lanternari, 1962) de una situación de opresión y explotación socioeconómica-, entiendo que el auge de conversión a Creciendo en Gracia responde, más bien, a argumentos de corte culturalista y psicologista.

Resulta indudable que esta situación - $y$ sentimientos consecuentes- ha dado pie a esa fuerte necesidad de liberación mesiánica y apocalíptica, máxime cuando la utopía que propone alude a una transformación corporal en el mundo terreno $y$ en un futuro próximo que acabe con la debilidad y habilite la apropiación y el disfrute de la "modernidad" desde una posición de poder. Así, lejos de tener un fin contraaculturativo y plantear el retorno nostálgico a la vida del pasado -como es el caso de los movimientos nativistas o revivalistas- que no logra colmar las aspiraciones vitales, su opción persigue la integración a otro modus vivendi que les permita asimilar y obtener cuantos bienes son envidiados o saciar el deseo de vivir tan bien como los demás. Quienes se suman a este credo anhelan con el Armagedón una era de cuño totalmente nuevo, una utópica situación aculturada en la cual obtener, siempre en esa realidad ideal y quimérica por venir, algunos de los elementos deseables del modus vivendi mestizo y occidental que su realidad no les puede proveer sin un costo económico y emocional tan elevado que los deja exhaustos (Neila Boyer, 2012b). ${ }^{22}$ Ese fin -donde ocurrirá la transformación corporal- resulta, por ende, una opción prometedora para acabar con la "frustración relativa" (Séguy, 1983) ante tantas expectativas y deseos sujetos a la "modernidad". Evidentemente, el desequilibrio entre lo que se posee y lo que se desea, y no sólo las situaciones de privación, ha estimulado aquí las condiciones idóneas para que se formara ese ejército de Jesucristo Hombre del que hablaba Carlos René.

\section{Imagine}

El 8 de mayo de 2012, escasas semanas después de que Jesucristo Hombre emitiera su despedida a toda su Iglesia -su "Amada"-, y semanas antes del fin del conteo regresivo para la fecha en que habría de ocurrir el Armagedón y la transformación de los cuerpos de los bendecidos (sus fieles), José Luis de Jesús

${ }^{22}$ Este aspecto del fenómeno milenarista se ha reportado entre otros pueblos amerindios como los ticuna (Vinhas de Queiroz, 1963). En esta línea, también son conocidos los cultos cargo melanesios emergidos tras el contacto con el mundo occidental (Worsley, 1980 [1957]). 
Miranda invitaba a sus oyentes a imaginar el mundo del futuro gobierno de la tierra con una retórica que recordaba, en todo, a la letra de la canción que en 1971 dio nombre al álbum de John Lennon, Imagine: ${ }^{23}$

Imagínate por un momento, bendecido, un mundo donde la naturaleza recobre su orden perfecto $[\ldots]$ donde las aves y los peces, y todos los animales, el curso de los ríos, esté en orden; la pureza de los océanos, los climas, sean normalizados. Un mundo sin hombres malos y perversos. ¡Eso sí va a ser lindo! -exclamaba antes de enunciar la corrupción y los abusos de la Iglesia católica y los gobiernos- [...] Un mundo sin contaminación, sin enfermedades, un mundo inmortal, con justicia. Un mundo sin margen de error, perfecto; un gobierno hermoso. ${ }^{24}$

El Ministerio Internacional Creciendo en Gracia (CEG), Gobierno de Dios en la Tierra, es una comunidad religiosa presente y en auge en 18 países de América Latina (además de Estados Unidos, Canadá, España, Italia y Alemania): $; 5$ fundada en 1973 por el puertorriqueño José Luis de Jesús Miranda, quien se decía contenedor de la mente de Cristo y se autoproclamó Jesucristo Hombre. ${ }^{26}$ Él era su segunda manifestación y, éste, el tiempo de su segunda venida; tiempo histórico gracias a la presencia de Dios en la Tierra que tendría su punto álgido en el Armagedón. Este evento se previó, en principio, para el 30 de junio de 2012;

${ }^{23}$ Imagina que no hay paraíso / Es fácil si lo intentas / No hay infierno debajo nuestro / Arriba nuestro, sólo cielo / Imagina a toda la gente / Viviendo el presente / Imagina que no hay países / No es difícil hacerlo / Nada por lo cual matar o morir / Y tampoco ninguna religión / Imagina a toda la gente / Viviendo la vida en paz / Quizá digas que soy un soñador / Pero no soy el único / Espero que algún día te unas a nosotros / Y el mundo será uno solo / Imagina que no hay posesiones / Me pregunto si puedes / No hay necesidad de codicia ni hambre / Una hermandad humana / Imagina a toda la gente / Compartiendo todo el mundo / Quizá digas que soy un soñador / Pero no soy el único / Espero que algún día te unas a nosotros / Y el mundo será uno solo.

${ }^{24}$ Calqueo del 8 de mayo de 2012: "Por qué es necesaria la transformación".

25 Tiene presencia en Argentina, Bolivia, Brasil, Chile, Colombia, Costa Rica, Cuba, Ecuador, El Salvador, Guatemala, Honduras, México, Nicaragua, República Dominicana, Panamá, Perú, Puerto Rico y Venezuela.

${ }^{26}$ En realidad, diciembre de 1973 es la fecha en que José Luis de Jesús Miranda -hoy con 67 años de edad- dijo tener una experiencia sobrenatural y ser poseído por "algo celestial" que se fundió con su cuerpo. A pesar de que a partir de este momento afirmara recibir revelaciones, no fue hasta 1986 cuando fundó oficialmente la organización en la ciudad de Miami (Estados Unidos). Por aquel entonces se autocalificó como "el otro", asegurando ser una especie de superser espiritual con la misión de sentar las bases para la segunda venida de Cristo. En 1993, durante la tercera convención del movimiento, fue proclamado "apóstol" por sus adeptos; y en 1999 declaró ser la reencarnación del apóstol Pablo. Posteriormente, en 2004, aseguró que era el mismo Jesucristo, y en los años siguientes hizo que sus seguidores le llamaran "Consolador","Salvador", "Dios" y "Padre". En 2007 exhibió el número 666 tatuado en el brazo y se autoproclamó como el Anticristo. 
fecha hasta la cual existió en su web un conteo regresivo. ${ }^{27}$ En este momento $-y$ empleo el tiempo presente porque la expectativa se mantiene viva- sostiene que tendrá lugar una catástrofe global ecológica y se producirá la destrucción de los no conversos. Ocurrirá, además, la transformación de su cuerpo y del de los bendecidos, que han convertido previamente sus mentes acuñando el evangelio CEG o "evangelio de la gracia", revelado al apóstol Pablo y recogido en sus 14 epístolas. ${ }^{28}$ Asimismo, será el final de un estado de cosas y marcará el comienzo de un nuevo reino en la tierra, un mundo que prevén más justo y regentado por un nuevo
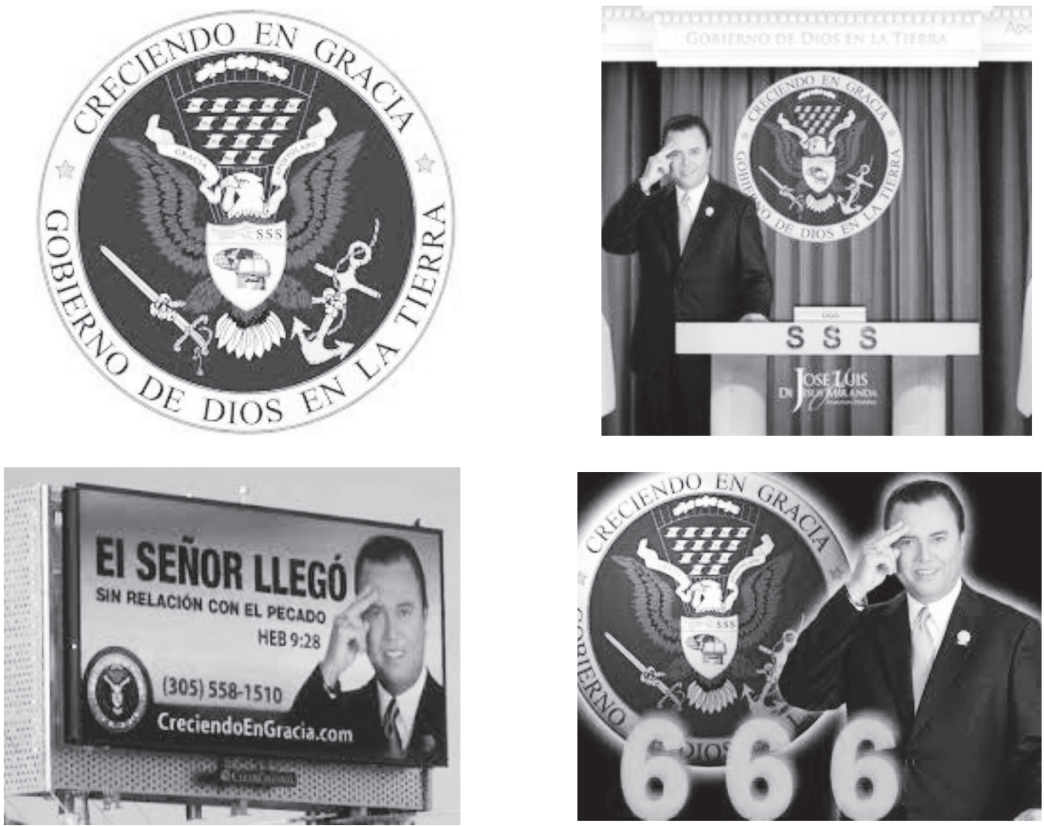

${ }^{27}$ El sitio <http://www.telegracia.com/creciendoengracia > (disponible en español, inglés, francés, alemán, italiano, portugués y ruso) aglutina decenas de sitios web oficiales temáticos con información acerca de José Luis de Jesús Miranda (JesucristoHombre.com), la crisis global (Crisis Global Hoy, sitio con información sobre "el día malo en la tierra"), casos de pederastia en la Iglesia católica (ProtegeATusHijos.org), noticias de calamidades y desastres naturales (NoticiaDeImpacto. com), un buzón de correo electrónico para los dioses (AposMail.com), grabaciones de jornadas de tatuajes de los bendecidos (666 Tattoos), foros para los bendecidos, clips doctrinales, un lugar biográfico, otro sobre la superraza, un canal de televisión (Telegracia.com, sitio oficial del Gobierno de Dios en la Tierra) y una emisora radial (Netgracia.com).

${ }^{28}$ Creciendo en Gracia estima que lo único verdadero de la Biblia son las 14 epístolas de Pablo; todo cuanto no sean ellas contiene un falso evangelio. El apóstol Pablo fue quien puso el "fundamento" del nuevo camino, denominado "la gracia" o la incircuncisión", mientras que el resto de apóstoles edificaron el "fundamento" de "las obras muertas": "la ley" o la "circuncisión". 
gobierno, con él a la cabeza. Desde 2009 vive aislado en Houston, Estados Unidos, desde donde dos veces por semana difunde a través de Telegracia (su canal de internet de 24 horas) "la palabra" a los bendecidos de todo el mundo, mediante calqueos, una de las ceremonias típicas CEG. De este modo reciben la doctrina de su líder, quien desde su escritorio y con una estética gubernamental norteamericana, sentado frente a las cámaras, maneja su "gobierno".

Así, Creciendo en Gracia profetiza la llegada de "un día malo" que, en ocasiones, en su retórica, escapa de sus límites temporales convirtiéndose en una etapa de varios años de duración que afectará a todo cuanto existe tal y como (en sus particularidades regionales) se conoce hasta ahora. Es más, advierte que, a la luz de ciertos acontecimientos sociales, eventos climáticos y catástrofes que anticipan el advenimiento del fin, ya se está viviendo ese tiempo; cuestión que conecta a la perfección con la idea tzotzil de ruptura del mundo y de nuevo vivir. El presente se vive como la antesala de ese último evento que se sentirá cual temblor que tumbará ciudades. Hasta entonces, creen, éste es un tiempo regresivo donde las catástrofes van a ocurrir más seguido:

el Ministerio va en conteo regresivo; cada día se va acercando más y vamos a ver las catástrofes. [...] lo que tú has visto es nada, porque lo que viene son ciudades cayéndose. [...] Ahora los científicos dicen que en el 2012, que va de acuerdo a la cuenta regresiva $[\ldots]$ se espera que viene un cambio sobre la faz de la tierra y que va a comenzar la destrucción del mundo, que nosotros entendemos que es la destrucción de un sistema. ¡Ojo! Que estamos bien cerquita del 2012, esto ya está apretando. [...] Posiblemente en el 2012 lo que va a ocurrir es que se va a hundir mucha tierra. [...] Habrá un lugar de reunión para los elegidos cuando nuestro cuerpo sea transformado, desde allí vamos a gobernar. [...] Entonces dice que comienzan inmediatamente los juicios sobre la tierra. O sea, que vamos a ver otro cataclismo.

Yo lo puedo más o menos ver de esta forma: cuando la Biblia dice que "en el principio la tierra estaba desordenada", es porque ese cataclismo que hubo desapareció todo, no había nada. Lo que quedó fue toda aquella civilización, todos aquellos animales prehistóricos, todo quedó sepultado bajo el agua. Luego Dios comenzó y también exterminó cuando vio en aquel principio que la gente era mala de continuo en su corazón, como está el mundo actualmente. Entonces luego utilizó a Noé bajo aquel diluvio, bajo aquel bautismo de agua que arropó todo, para comenzar de nuevo con la incircuncisión. [...] Dios va a comenzar un orden nuevo sobre la faz de la tierra con la incircuncisión [...] con aquellos que él predestinó y les dio el don de la fe para creer como tú y yo creemos, aquellos que Dios ha llamado y ha alumbrado. Ésos sólo son los que van a gobernar conmigo. 
Vienen unos momentos preciosos, no es para asustarnos bendecido, porque nosotros amamos la justicia y hemos sido gente alumbrada con este evangelio. Tú lo que vas a hacer es gozarte porque vienen los mejores días sobre la faz de la tierra y tú vas a ser guardado. Mira que ese terremoto que viene cual jamás han visto los hombres sobre la faz de la tierra, eso caerá sobre ellos, por eso tú has sido guardado. ${ }^{29}$

Pero en este presente convulso y tiempo regresivo afirman que la creación "gime" por su existencia violentada y maltratada a manos del hombre -tanto en términos ecológicos como sociales-" "gime porque ha sido muy abusada -sostiene Jesucristo Hombre-, se están extinguiendo los animales, la ecología, los aires contaminados, el agua hay que estar purificándola, los alimentos están dañados, los gobiernos están dañados [...] Gime esperando que se levante un gobierno que sane a la naturaleza". Sólo con la llegada del Armagedón, y la consecuente trasformación al evangelio de la gracia, será posible aliviar esta situación:

porque con el conocimiento y la sabiduría ésos que van a ser transformados no van a querer hacer daño -dice-, todo lo que buscan es bien; porque al quitarles la corrupción que hay en la carne todo lo que va a haber es bondad. No habrá cárceles, no habrá hospitales porque no habrá enfermedad. Hasta la moneda será cambiada. Hace falta un cambio tremendo porque todo está dañado. ${ }^{30}$

Mientras este momento llega, la "Amada" va progresando en número de "elegidos", quienes se tatúan el 666 - "el sello de Dios Vivo"- como signo que identifica a Jesucristo en su segunda venida y marca a los bendecidos como parte de ese Nuevo Gobierno de la tierra. ${ }^{31}$ Esta cifra, cuyos números dicen representar y celebrar precisamente la destrucción del diablo, la desaparición del pecado y la victoria sobre la muerte, es señal de prosperidad. ${ }^{32}$ Ellos no sólo creen vivir los

${ }^{29}$ Calqueo del 2 de marzo de 2011: "Armagedón".

${ }^{30}$ Calqueo del 6 de mayo de 2012: "Los cielos".

${ }^{31} \mathrm{Al}$ respecto, por ejemplo, advertía uno de sus colaboradores: "Se sabe que son de papá por su marca. Dios siempre marcó a su pueblo y hoy en día nosotros llevamos este numerito que significa que el diablo fue destruido, que el pecado fue quitado. 666, número de prosperidad; SSS, salvo siempre salvo'. Nos sellamos porque somos parte de un gobierno. Nos identificamos con José Luis". Para una mayor descripción acerca de su significado, véase <http://www.telegracia.com/666/>, el apartado referido al mismo, y calqueo del 16 de septiembre de 2011 titulado "Caer de la Gracia".

32 Otros principios básicos de CEG hacen referencia a la preexistencia, antes del nacimiento, a la doctrina de los pequeños dioses y a la capacidad creadora de la "confesión positiva". Respecto a las dos primeras, se entiende que Dios es el padre de los espíritus y los creó antes de la fundación del mundo. De manera que hay una existencia como ángeles antes de la terrenal en que Dios les predicó "El evangelio de la salvación" previo envió a la Tierra. La comprensión de esta realidad, según 

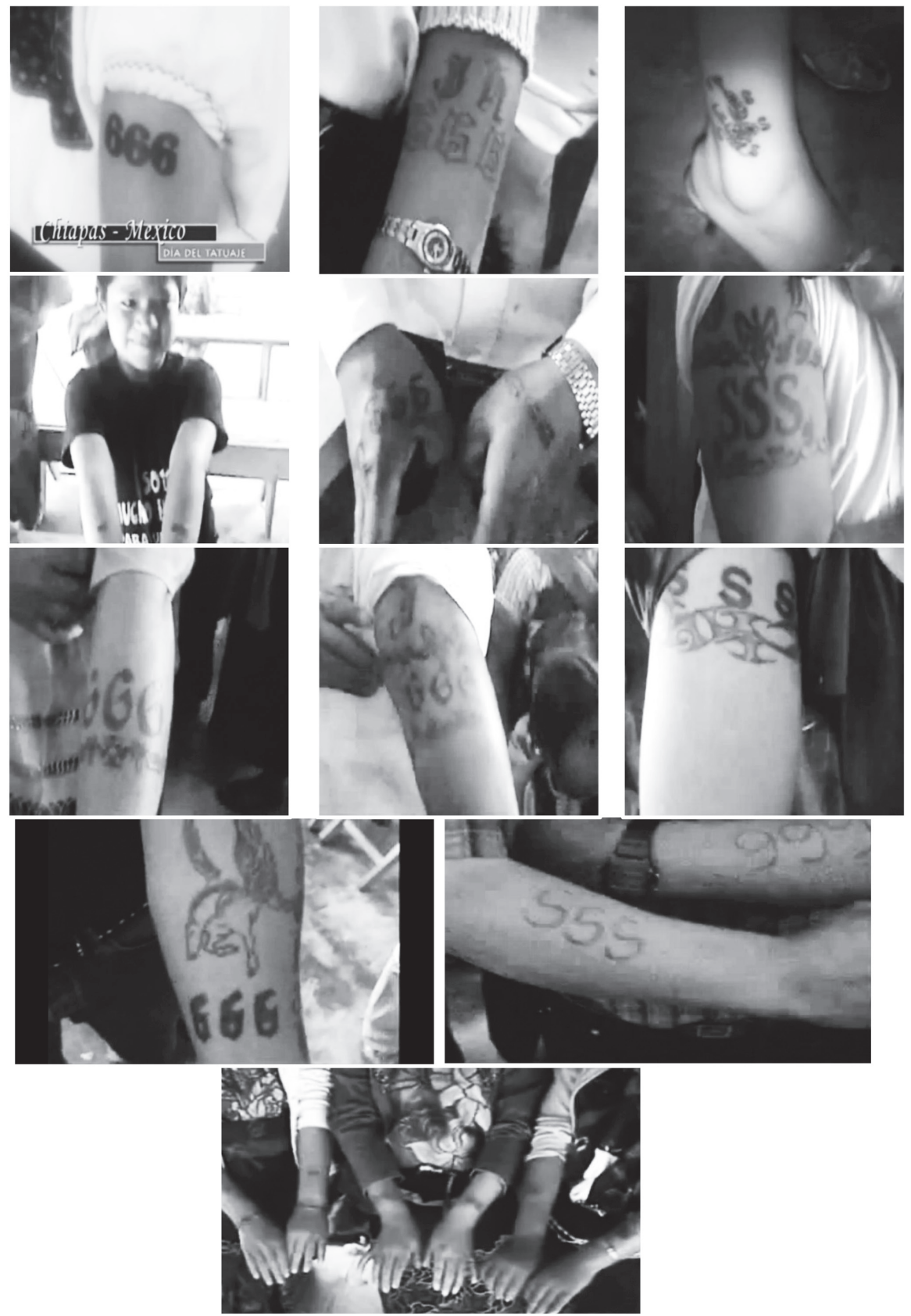

Fuente: Fotos extraídas del video Miles se tatúan el 666 en Chiapas, México <http:www.youtube.com/ watch?v $=$ wmvV2KRhad0 $>$ [24 de agosto de 2013]. Cuenta de You Tube asociada al video, cancelada. 
días del "Hijo del Hombre", salvos de ese futuro "día malo", ${ }^{33}$ sino que, además, con ello aspiran a la felicidad y a una existencia tranquila libre de los sobresaltos cotidianos (materiales y emocionales) del nuevo vivir, al creerse completos, limpios, sanos y glorificados. Marcarse con el 666 significa "quitarse el velo", "activar" la fe de Creciendo en Gracia y reclamar la perfección; herencia que, sostienen, quedó para el hombre con la crucifixión y muerte de Cristo:

[Q]uitarte el velo es decirte: "no mires antes de la cruz porque ahí está la ley [los mandamientos]. Ahí está la maldición. Ahí está la condenación". Si miras después de la cruz te ves perfecto. Sin faltarte nada. La fe que te dice:"no busques más a Dios porque ya lo tienes dentro". [...] Porque el Espíritu de Dios, en el tiempo antes de la cruz, venía y se apoderaba una fuerza, venía y se iba [...] porque estaban en pecado y el Espíritu de Dios no puede morar donde hay pecado. Pero después de la cruz, al quitar el pecado, vino para quedarse. Por eso es que la vida de Cristo está en ti; tú tienes todos los derechos de reclamar tu herencia porque estás completo, limpio, santo y bendecido. [...] En cuanto al aspecto de cuando tú partes del cuerpo, los católicos dicen: "tienes que ir al purgatorio porque ese espíritu está manchado". [... Y Y entonces, cuando se muere el individuo, hay que hacerle las misas... Toda esa basura de Roma [... Cuando Cristo muere quita la muerte y ya tú no tienes que estar con esa basura. [...] nosotros hemos dado mucho ejercicio en que estamos perfectos, estamos completos, somos escogidos, predestinados, bendecidos. Bueno, ya el velo fue quitado, ya el bien lo tenemos bien dominadito. Estamos equipaditos. Entonces Satanás es un periódico de ayer, destruido. El único poder que él tiene es el que tú le das. No le des lugar a tus concupiscencias, a tu humana debilidad. ${ }^{34}$

Supone, en definitiva, romper con un tiempo de carencias e imperfección que, según su doctrina, quedó subsanado con la muerte de Cristo en su primera venida, pero oculto y desconocido hasta ahora; hasta que nuevamente Jesucristo se hizo presente en la tierra en la figura de José Luis de Jesús Miranda y comenzó a predicar el Evangelio de Pablo, basado en la reconciliación, frente al de Pedro, sustentado -dicen- en el arrepentimiento. ${ }^{35}$ De este modo, convertirse a

CEG, sólo se logra cuando se alcanza la madurez espiritual máxima, es entonces cuando se entiende que se es un ángel y un dios.

33 Calqueos del 8 de diciembre de 2010, "El día malo y el 666", y del 26 de enero de 2011, "El conteo regresivo".

${ }^{34}$ Calqueos del 10 de junio,"La fe del evangelio", y del 27 de septiembre de 2012,"El conocimiento del bien y del mal".

35 En el calqueo del 6 de mayo de 2012, “Los cielos", afirmaba:"Él [Jesucristo] reconcilió todo lo que estaba en el cielo y lo unió con todo lo que está en la tierra; y de aquí se va a formar un gobierno 
Creciendo en Gracia es apostar por las buenaventuras en el mundo de aquí y en un tiempo próximo a acontecer. Ésa es su promesa y su éxito, al menos en Chiapas. Como expondré en el siguiente apartado, querer alejar la debilidad (sentida en la forma de nuevas enfermedades-ach' chamel-) bajo la creencia de que la muerte de Cristo en el pasado les redimió de todo mal y ahora (de entre esa retahíla de estados positivos que emplean) están perfectos y fuertes; pueden sentirse escogidos y predestinados, en vez de marginados y excluidos en los múltiples ámbitos de su vida cotidiana. Tanto así, que las promesas de Creciendo en Gracia y el significado que le atribuyen al 666 conducen a presumir un estado de prosperidad y bienestar posible y alcanzable sólo con la conversión. "Quitarse el velo" y creer parece ser el camino de un nuevo "buen vivir", preludio de esa esperanza utópica que ponga punto y final a este mundo/tiempo/sociedad que consideran roto ${ }^{36}$ Así, mientras otros dogmas velan por el destino del espíritu y sus condiciones en el más allá, Creciendo en Gracia hace referencia a la perfección del cuerpo y el bienestar presente, a la "salvación diaria" que puede alcanzarse siempre y cuando la persona haga oídos sordos a los deseos y delirios de la carne (del cuerpo), heredera, dicen, de los atributos de Satanás y siempre dispuesta a importunar porque:"Cristo vino e hizo tu espíritu perfecto pero la carne se quedó en su condición 'diablo'. [...] el diablo carne está llamado a oponerse a ti, a decirte: 'No vas a poder. Mira lo malo que están las cosas'. [... ] Pero tu espíritu está supuesto a ir en contra de eso". De ahí que sostengan que son espíritus gobernando carne y afirmen con insistencia que "la salvación no es para tu espíritu, porque la salvación de tu espíritu tomó lugar en la cruz del calvario. Cuando Pablo habla de 'salvación' es la salvación diaria". ${ }^{37}$

que lo veo difícil en carne, con el cuerpo como lo tenemos, pero con una transformación de cuerpos glorificados entonces él formará un reino en este mundo". Para profundizar en el sentido de esta "reconciliación", véase el calqueo del 1 de julio de 2012 titulado "El ministerio de la reconciliación".

${ }^{36}$ En este sentido, Creciendo en Gracia se encuentra influenciada por lo que se conoce como el Movimiento de la Fe. Éste postula que el creyente puede crear su propia realidad a través del pensamiento o la confesión positiva. De manera que, cuando los bendecidos están pasando por una situación difícil, se les recomienda expresarse del siguiente modo: "Señor no recibo esto, recibo que esto se arregla, digo que esta situación cambia ahora mismo. Habla a tu carne que le encanta enfermarse y resfriarse. Dile: '¡mira!, sánate que no tengo tiempo para eso, sánate, te declaro sana'. Hable duro, con poder, tú tienes la vida en tu boca".

${ }^{37}$ Calqueo del 25 de marzo de 2012: "Los rudimentos y los ángeles". Respecto a la idea de ser espíritus gobernando carne, en el calqueo del 24 de mayo de 2012,"El virus y la religión”, José Luis de Jesús Miranda exponía: "cuando Adán pecó y entró en esa desobediencia con Eva, pues el cuerpo físico perteneció al diablo. [...] Y todavía sigue latente la corrupción en tu cuerpo. [...] el cuerpo se quedó en corrupción y el evangelio ha sido dado para tratar con el cuerpo. [...] Entonces lo que aprende obediencia es el cuerpo tuyo. ¿Y cómo se aprende esa obediencia? Pues por el trato angelical que Dios le da a ese cuerpo. Porque él va buscando tu atención hasta que obtiene que tú 


\section{¡Pero no son los mayas!, es el evangelio...}

La arquitectura teológica de Creciendo en Gracia está, sobre todas las cosas, orientada a atajar la debilidad y proveer bienestar. Como hasta ahora defiendo, éste parece ser el motivo de su auge entre la población indígena tzotzil de Chiapas, la cual, a su condición de marginación y exclusión social histórica ha de sumar los duros condicionantes impuestos a la vida cotidiana como efecto de la supuesta modernidad. Más allá de incumbir a recursos materiales, también aluden a la fractura social característica de este nuevo vivir, la cual ha exacerbado los conflictos $y$, en consecuencia, atraído a las que han denominado nuevas enfermedades. ${ }^{38} \mathrm{Si}$ bien son muchas las cosas "modernas" que gustan de consumir, tales "antojos" son también maneras de ser, hábitos y emociones que provienen de la "modernidad" y se asocian con la exageración del carácter y una sangre demasiado fuerte -síntomas de una apertura emocional- y resultan conflictivas por chocar frontalmente con las tradiciones y la costumbre, originando emociones patógenas o aflicciones emocionales (Groark, 2005). ${ }^{39}$ Consumir descomedidamente nuevos

tengas temor a él. [...] nosotros no somos carne adaptando al espíritu, nosotros somos espíritus gobernando carne".

${ }^{38}$ Éstas son dolencias fuertes, graves, crónicas y letales; incurables con los remedios naturales y por los métodos tradicionales. Se desconoce su procedencia y resultan inquietantes; existe alarma y vigilancia continua - posible de notar en cualquier conversación cotidiana- donde se explicita la tremenda preocupación que experimentan con su presencia. La asociación entre ellas y el nuevo vivir es evidente, cuestión que les provoca un estado de ánimo de permanente incertidumbre debido a las sospechas hacia lo moderno, $y$ de perpetua vulnerabilidad por concebir la contaminación de lo tradicional. Tanto así, que no hay a quien no le resulte cierta su relación con la multiplicidad de nuevos artículos que pueden comprar en un contexto de mercado; tampoco quien discuta que les rondan porque desconocen qué están consumiendo en la medida en que ellos no controlan su producción. También es obvia la razón de cómo las cosas antiguas, antes sinónimo de vitalidad y bienestar - por ejemplo, los productos de la milpa-, se han corrompido hasta el extremo de poder causar cualquier daño. $Y$, a pesar de todo, son cosas que gustan de consumir y lo hacen de manera habitual y excesiva.

${ }^{39}$ En un magnífico trabajo sobre el cambio socioeconómico y la enfermedad de chuvaj, "locura”, Collier et al. (2000) exploran -a partir del concepto de embodiment (incorporación) - cómo la experiencia de las contradicciones y dilemas que plantea una economía en rápida evolución -o los procesos de diferenciación socioeconómica (agraria y comercial) - y su repercusión en las relaciones sociales, políticas y culturales afectan el bienestar y la salud de las familias de las comunidades mayas de Los Altos de Chiapas mediante el padecimiento de esta aflicción, entendida como expresión de la angustia o el sufrimiento emocional (distress emotional) entre tzeltales y tzotziles. Esta dolencia, muy cercana y a veces confundida con el mé vivik (ach' chamel paradigmática), es decodificada como parte de un discurso a través del cual se manifiestan los conflictos, no sólo personales o interpersonales, sino reflejo, además, de la marginación del estilo de vida maya en Los Altos. Por ende, las contradicciones que afloran por efecto del cambio respecto de los medios de vida, y la vida misma de las personas, se prestan a ser interpretadas como relaciones sociales que han ido mal y que, a 
alimentos (como metáfora de un "moderno" consumo desmedido) y no controlar la elevada carga emocional de las interacciones sociales -o el descontrol emocional que parece caracterizar el nuevo vivir- parecen atraer a las ach' chamel, las cuales dan la impresión de contaminar el ambiente cotidiano cual nube tóxica. ${ }^{40}$ En este sentido, y entendiendo las enfermedades como lenguaje, éstas parecen hablar-sobre todo- del esfuerzo adicional que el ach' kuxlejal demanda en la vida cotidiana en los ámbitos económico y emocional (Neila Boyer, 2012b); además de los peligros desestructurantes y disruptores de todo lo foráneo que, de manera inevitable y por gusto, se integra a la cotidianidad indígena. Así resulta, precisamente, por el estado de debilidad que las significa; al grado de que éstas parecen reflejar la condición social tzotzil actual; y dan la sensación de la "modernidad" imbuida por el malestar y la aflicción con síntomas debilitantes para la persona y la afectación de aquellas partes del organismo ( $y$ sus funciones) que culturalmente se relacionan con la fuerza y la razón, pilares de la costumbre y requisitos para el lekil kuxlejal (Neila Boyer, 2013). El padecimiento de las ach' chamel se vive como incapacitante y revela un sentimiento de debilidad generalizado que da cuenta del clima social y emocional de inestabilidad que consume los recursos culturales y desgarra el tejido nervioso y comunitario en Los Altos de Chiapas. Es posible afirmar, entonces, que éstas denotan los sentimientos de inseguridad, vulnerabilidad y extenuación tzotzil frente al nuevo vivir. Pero si, como digo, el presente es este tiempo de fatiga y apocamiento, el futuro no deja de ser, aparte de ignoto, un tiempo/espacio de esperanza donde -junto a la medicalización de la vida cotidiana- la conversión religiosa se erige como promesa de superación de esa condición que abunda en la fragilidad tzotzil respecto de la "modernidad".

En este contexto, la adopción del catecismo CEG y el abrazo del "evangelio de la incircuncisión" se publicitan como el único antídoto, la medicina exclusiva, para evitar la debilidad y restaurar la fortaleza perdida. Una receta, según dicen, escondida durante más de dos mil años por el resto de las religiones, que han

su vez, se incorporan como enfermedad. Tzeltales y tzotziles describen este estado con la misma raíz verbal con que refieren la oscuridad: tup. Para aquellos cuya visión se oscurece, el mundo se vuelve carente de sentido; tal percepción se halla asociada al hecho de que tengan que despojar su vida de significado, por conceder validez a los aspectos de la cultura en plena evolución.

${ }^{40}$ La conmoción de las relaciones resulta un potente atractivo para las ach' chamel pues, cuando se ventilan, generan conflicto y, cuando se reservan para sí, provocan enfermedad. Estas dolencias, producidas por la tristeza intensa, la rabia u otras emociones extremas, pueden conducir a diferentes afecciones conceptualmente coincidentes y estrechamente vinculadas tanto en su sintomatología como en su causalidad: "dolor de corazón” (k’ux o’nton), "mamá del hombre” (me’ vinik), "corazón febril" (k'ak'al o'ntonal), y se amalgaman en torno a una vorágine de síntomas que orbitan alrededor de la debilidad (Groark, 2005; Collier et al., 2000; Neila Boyer, 2012b). 
dañado la mente dando rienda suelta a la maldad y al sufrimiento: "la religión nos hizo mucho daño, nos dañó la mente. Por eso es que hay tanta maldad, porque la mente está dañada, y por eso está la mala conciencia y sufrimos". Así, la segunda venida de Cristo -en el tiempo presente- responde, según José Luis de Jesús Miranda, al último intento divino de ofrecer una existencia en poder $y$ salvación:

el Viejo Testamento no pudo con las debilidades. Dios les dio diez mandamientos y entonces nadie pudo cumplirlos. Entonces Dios dijo:"Esto es trabajo de Superman, de un superhombre". Se llamó Jesús de Nazaret, pero como hombre vino y cumplió la ley totalmente. [...] Y murió por nosotros y dejó un antídoto para la debilidad, dejó una medicina para que el débil sea fuerte. [...] Por dos mil años las religiones han escondido esa medicina. [...] él hizo un plan para que tú vivas en poder. Se llama el evangelio de la incircuncisión. Eso le da poder a uno para vivir en salvación. ${ }^{41}$

Esa receta o plan velado durante milenios por la acción de otras iglesias considera la promesa de tres bienes o gracias que confieren fortaleza y poder a las personas: la transformación de la mente mediante la acción sobre ella del espiritu de gracia, la cobertura angelical y la transformación del cuerpo. Los dos primeros son recursos que Creciendo en Gracia ofrece a los bendecidos antes del Armagedón. Comienzan a actuar desde el instante de la conversión al evangelio de la incircuncisión y operan de manera progresiva, aunque cada uno de ellos despliegue su particular forma de no dar cabida a la debilidad. Pero además de un potente repelente contra ella son, sobre todo, requisito imprescindible para la futura metamorfosis que convertirá a la persona en un "fenómeno inmortal". Dar aforo al espíritu de gracia mediante la conversión es el paso previo hacia ese momento culmen y profético e implica la educación de los pensamientos y la reforma del espíritu, hecho que denominan quitar el velo: "una persona que le quitan el velo ha resucitado ya con Jesucristo, en el aspecto mente; el cuerpo es transformación" ${ }^{42}$ Ambas se consiguen casi de una forma parasitaria, pues se afirma que el espíritu de gracia es una "ciencia" que se deposita en la mente; lugar desde el cual comienza a surtir efecto en dos esferas si el sujeto se entrega a ella y no opone resistencia: favorece, por un lado, una vida saludable y, por el otro, proporciona una existencia feliz. En definitiva, redunda en la salud evitando gastar recursos en médicos o en medicinas y provee felicidad en tanto "trabaja" sobre todas

${ }^{41}$ Calqueo del 14 de marzo de 2012: "La debilidad de la debilidad".

${ }^{42}$ Calqueo del 4 de enero de 2012: "El único". 
las necesidades humanas, lo que en última instancia elimina el sentimiento de desolación (soledad, desamparo, pesimismo) existencial:

El espíritu de gracia, si usted no le hace afrenta y usted se entrega, se le mete y empieza a trabajar con usted. [... ] No tengo que estar gastando dinero en medicinas. No tengo que estar en un médico. [...] Y esto afecta todo [...] se mete por todas partes. La gracia hace cosas maravillosas, de la "a" a la " $z$ ". [...] ¿Cuáles son las necesidades humanas? [...] son las que la gracia coge y [...] trabaja. [...] para que tú no estés en desolación debes prestarle atención al espíritu de gracia. Tú cultivas este conocimiento. Esto es un negocio redondo, como dicen los comerciantes, porque si tú amas la vida y tú amas ser saludable, y amas ser feliz, pues tú tienes que entregarte a este espíritu". ${ }^{3}$

Se trata, pues, de cultivar mentalmente el evangelio de la incircuncisión, con la garantía de que así la gracia participará en un trabajo colaborativo por conseguir el bienestar personal. Con la promesa de la salud y la felicidad, la conversión a CEG de muchos indígenas chiapanecos es interpretada no sólo como una doctrina o como un negocio redondo, sino, en efecto, como una ciencia acerca de la forma de vivir la vida: un estilo de vida positivo que marca la diferencia entre los bendecidos y el resto de la humanidad, distinción que es expresada en términos de salud, pero, sobre todo, en una mayor facilidad para vivir:

esto no es una religión, esto es una ciencia que cuando se deposita en tu mente comienza a causar unos efectos. Y eso va poco a poco. [...] Y de momento tú te das cuenta: "¡oye!, yo me siento tan bien”. [...] la gracia no es sólo una doctrina, la gracia es la ciencia de cómo tú vivir la vida. [...] es un estilo de vida. Tú sabes lo que es levantarte diferente, pensando diferente. Las tensiones que tú le quitas a la mente. [... ] toda esa serie de cosas van entrando allí. [... Usa lo que Dios te dice que debes hacer y la vida se te va a hacer más fácil. Y te vas a mantener más tranquilo. Y las enfermedades te van a odiar. Con esta actitud las enfermedades no se acercan. Tú no ves que lo que atrae la enfermedad es el "negativismo" de la carne endiablada que tú tienes. [...] Tú eres una raza especial, entonces tienes que educar tus pensamientos. Oye, di conmigo: "yo no me contamino. Yo no voy a meter temor en mi mente. Yo soy lo que pienso. Yo ando en mucha salud. Tengo todo mi cuerpo sano; mi corazón, mi sangre corre bien por mis venas. Todo lo tengo bien, los tejidos, todo me crece normalmente". ${ }^{44}$

43 Calqueo del 25 de julio de 2012: "Desolación".

${ }^{44}$ Calqueos del 25 de julio, "Desolación"; del 1 de agosto, "Una generación especial", y del 4 de abril de 2012,"El consolador y el mediador de un nuevo pacto". 
De alguna manera este espíritu de gracia guarda relación con el servicio angelical que trabaja en la vida de la persona para ayudarla ${ }^{45} \mathrm{~A}$ pesar de que Creciendo en Gracia afirma que cada quien, desde antes de su nacimiento, posee un ángel a su servicio que interviene constantemente en su existencia regulándola, modulando las "malas costumbres" culturales, no es hasta que los bendecidos abrazan el evangelio de la incircuncisión que sus acciones y su voz -a modo de conciencia CEG- lo proveen de una cobertura angelical sin la cual, en estos tiempos convulsos -antesala del Armagedón y la transformación-, quedarían a la deriva. Este servicio de ángeles poderosos cuidan con celo y esmero a sus protegidos y ofrecen, sobre todo, salud y prosperidad. Tanto así que, además de abarcar todo tipo de necesidad, mantienen que "la salud es la Cobertura de José Luis", quien advertía a sus seguidores: "tú no tienes que venir para Estados Unidos a nada. Te puedes quedar en tu país y allí la Cobertura te hace provisión. Con esta Cobertura hay prosperidad, no importa donde tú estés"..$^{46}$ Además, exime a las personas de las preocupaciones y luchas cotidianas, quienes deben delegar en los ángeles la resolución de cualquier conflicto que provoque ira:

Cada uno de nosotros tiene un ángel. Tú no puedes funcionar sin su servicio. O sea, como ser humano en un pacto de gracia tú no puedes estar sin ellos. El ángel tiene que intervenir constantemente en tu vida. [...] desde el vientre. [... [ ¿Por qué las religiones tienen reglas? Porque ellos no tienen una cobertura angelical. [... ] Aquí no hay reglas, aquí tú puedes hacer lo que te dé la santa gana. [...] el ángel es quien regula tu vida. [... ] Entonces los ángeles son tus mejores amigos, son los que ejecutan tu salvación, son los que te dan esos deseos de tu corazón. Piensa en una necesidad que tú tengas, una sola. Allí están ellos diciendo: "lo que es imposible para ti para nosotros es posible". [...] Los ángeles lo hacen mejor que tú. Tú no tienes que defenderte tanto. Aun cuando hablan mal de ti, tranquilo, no acudas a la ira, deja las cosas quietecitas, deja que los ángeles lo hagan por ti, que ellos te respaldan. [... ] tú tienes una cubierta de ángeles que tú tienes derecho de reclamar sanidad y esos ángeles que están pendientes de ti se manifiestan a favor tuyo. [... ] No lo hagas tú, deja que los ángeles traten. ${ }^{47}$

${ }^{45}$ En el calqueo del 25 de julio de 2012,"Desolación”, Jesucristo Hombre expresaba: "Esa cobertura es una cobertura invisible, espiritual. Entonces esos ángeles están enviados para ayudarte, el servicio angelical. Eso es lo que va a trabajar en tu vida”.

${ }^{46}$ Calqueo del 28 de octubre de 2009: "La cobertura angelical".

${ }^{47}$ Calqueos del 30 de mayo, "El ángel que nos sirve"; del 24 de mayo, "El virus y la religión”; del 25 de marzo, "Los rudimentos y los ángeles", y del 4 de abril de 2012,"El consolador y el mediador de un nuevo pacto". 
Pero lo sustancial es que, hasta finales de junio de 2012, los bendecidos chiapanecos, como los del resto del mundo, se encontraban inmersos en un conteo regresivo hacia la transformación de su cuerpo o, mejor dicho, hacia su revestimiento con un nuevo ropaje "radioactivo" que habría de librarlos de la debilidad y convertirlos en hombres nuevos, al estilo de los héroes de cómics como Superman, Flash Gordon o Iron Man. La transformación haría de sus cuerpos organismos mejorados, libres de enfermedad, inmortales e incorruptibles, perfectos y poderosos; diferentes de los de ahora en cuanto estarían conformados por un material enérgico, vigoroso y potente como la radioactividad. Ello igualaría también a los "Escogidos del Señor" en este "Gobierno venidero" con aquellos seres bíblicos incandescentes, ${ }^{48}$ en consecuencia, a las personas les esperaría algo más excelente que la resurrección del espíritu: su transformación aquí -en la vida terrenal-en entidades poderosas y "sin margen de error"; al grado de que ni siquiera necesitarían comida para funcionar, pues ese cuerpo renovado no tendría apetito y la ingesta de alimentos sería más un deseo que una necesidad. La enfermedad, la muerte y la pobreza no les afectarían; estarían "probados por fuego", "reinando en vida", en triunfo, sanos, en abundancia, prósperos y con un buen estado anímico. ${ }^{49}$ La incorrupción de la carne vendría "metiendo átomo", "metiendo radioactividad"; los bendecidos se constituirían en una comunidad de "dioses poderosos atómicos". Con ese cuerpo omnipotente regirían con Jesucristo Hombre como "gobernador", "como Dios a la cabeza". La explicación de cómo sería ese vestido incorruptible, y cuáles sus cualidades, la ofreció José Luis de Jesús Miranda en diferentes calqueos dictados en 2011 y 2012:

la vestimenta de nuestro cuerpo, cuando lo inmortal absorba la muerte, va a ser de un material como la radiactividad, como el poder. [... Casi siempre ese poder sale de los seres que hemos visto en la Biblia, como esos carros de caballo de fuego, nuestra

${ }^{48}$ En el Calqueo del 6 de abril de 2011, Jesucristo Hombre, en el transcurso del relato de sus revelaciones, les dijo a sus fieles: "Hace poco yo tuve una revelación de que yo tenía en mis manos como un maletín de madera grande, entonces se me escaparon como unos neutrones, unos átomos; como una radioactividad que se salió. Entonces, cuando se salió, yo traté de recuperarlo pero no podía agarrarlo. ¡Qué pasa!, que eso tenía un poder tan tremendo [...] inmediatamente pasé a una segunda parte de la revelación donde yo estaba en un automóvil que el agua le subió casi hasta la puerta y apagó el automóvil. Y yo vi el peligro que estaba corriendo y de momento sentí que jalaron el carro así, y lo pusieron a salvo [...] al ponerlo a salvo yo hablé y pregunté... Porque como yo veía esas partículas radiactivas que no se movían del lado mío, pues yo hablé con ellos y les dije: ¿Fueron ustedes los que me salvaron el automóvil? Entonces me contestaron afirmativamente [...] Quiere decir que esos ángeles son tan poderosos que lo que la gente ve por ahí: fuego, platillos voladores o ciertas cosas, siempre lo ven en fuego y para mí ésa es parte de la vestimenta que nosotros vamos a ser vestidos $[\ldots]$ supermanes modernos".

49 Calqueo del 19 de enero de 2011: "Probados por fuego". 
vestimenta va a ser hecha de ese material [...] Nosotros no estamos esperando resurrección. [...] Las primicias de este llamado para gobernar sobre la faz de la tierra son cuerpos incorruptibles, cuerpos diferentes vestidos de un material diferente. [... ] lo que nosotros esperamos es algo más excelente. [... ¿ ¿Te recuerdas las películas de Flash Gordon? Aquellos episodios [en] que tú veías [...] celulares que ni existían y él siempre soñaba con una vida futura... Porque Dios siempre usa al hombre, aun sin ser alumbrado, sin ser cristiano, el corazón de su creación se imagina cosas que él anhela como un Superman. Pues, mira, esto es como un Iron Man. ¿Tú has visto esa película? Que es un cuerpo poderoso. Pues la gente sueña con esto, así van a ser nuestros cuerpos. Nosotros vamos a tener [...] un cuerpo eterno, no muere [...] incorruptible, poderoso, perfecto. Así que estamos hablando de unos cuerpos maravillosos [...] esta carne no aprovecha para nada, ni aprovechará nunca para nada. Esto hay que cambiarlo, hay que meterle incorrupción, hay que meterle átomo, atómico. Hay que meterle radioactividad con todas las herramientas para formar un cuerpo eterno, maravilloso [...] éste es el nuevo traje: carbunclo, que viene de carbón.

[...] Adán poseía un cuerpo tremendo, un cuerpo poderoso, era un Superman, era un Iron Man de ésos; era un fenómeno de personaje. Pero al pecar perdió las vestiduras; al perder las vestiduras quedó en lo que somos nosotros hoy: en carne y sangre que no hereda. Por eso nosotros anhelamos ser revestidos de aquella gloria que tuvimos del hombre celestial.

[...] Nosotros vamos a ser una comunidad de dioses poderosos, atómicos, con un poder maravilloso ante el mundo; será un espectáculo mundial de la ropa que nos van a poner [...] Imagínate, ¡seres inmortales! ¡Es maravilloso! [... Éste va a ser el último año hacia la trasformación, el último año hacia el final del conteo para todos nosotros, los que hemos sido alumbrados [... L La salvación de nuestro espíritu tomó lugar hace 2000 años [...] El problema es el cuerpo tuyo. [...] Nosotros somos los entendidos y fuego para nosotros es ropaje, donde estaba Adán al principio, que se paseaba ahí entre las piedras de fuego y tenía un ropaje bellísimo de todas las piedras preciosas. Eso es, se deshace este tabernáculo que tenemos de carne, entonces viene el revestimiento de ese ropaje especial que el sistema ni se imagina. [... ese ropaje viene y ¿tú sabes cuál es ese ropaje? Si es indestructible y es eterno, no puede ser de carne, porque la carne no hereda las cosas incorruptas. La carne todo lo que tiene es corrupto: te viene la enfermedad, te viene el cáncer, te viene el desgate físico, te vienen problemas por todas partes. Dios no puede hacer un reino así tan débil.

[...] después de la transformación son muchas las cosas maravillosas que podremos hacer con nuestros nuevos cuerpos. No habrá barrera que nos impida nuestra 
nueva funcionalidad de gloria en los cielos, recibiremos nuevas fuerzas en todas las áreas de nuestro ser, tales fuerzas nos permitirán correr sin cansarnos y caminar sin fatigarnos [...] ¡Mira!, aquí no hay necesidad de comer. Por lo tanto no se va a defecar. Es un cuerpo, ¡mira!, ni aceite necesita para funcionar. Es un cuerpo perfecto, sin margen de error, poderoso, eterno, para siempre. Eso es lo que tiene Papá para sus hijos en este Gobierno Venidero [... ; Maravilloso! Pero lo singular y extraordinario de todo esto es que con estas nuevas fuerzas levantaremos alas como las águilas, como los ángeles [...] Andaremos en el espacio como lo hacemos hoy, físicamente, sobre la tierra. [...] Vamos a tener esas naves espaciales, veintenas de millares, cada cual tendrá su automóvil. Olvídate de los dealers (agencias de venta) de carro y las cosas que tú ves por ahí que se desbaratan, se ponen viejos y deprecian. Ésos no deprecian y corren a una velocidad sin margen de error. Eso es lo que le espera a los bendecidos. [...] Los mayas lo que tuvieron fue una leve visión de que venían una serie de personas que tenían unas características buenas y maravillosas, ipero no son los mayas!, es el evangelio eterno que se predica debajo del cielo, que se le ha encomendado a Jesucristo Hombre para decir estas cosas que jamás se habían dicho. ${ }^{50}$

A pesar de que tras el 30 de junio de 2012 nada ocurriera -excepto la desaparición del conteo regresivo-, la idea tzotzil de que en la "modernidad", ach' kuxlejal, la vida y las personas han cambiado de una manera irremediable e irreversible - de una condición de tradición/costumbre y fortaleza propiamente indígena a otra de nuevo vivir y debilidad más característica de lo que imaginan como el mundo mestizo- mantiene viva la esperanza de que a la ruptura del mundo, a la ladinización de su cotidianidad y a la "descaracterización cultural" (Barabas, 2008) les suceda algún acontecimiento que ponga punto final al deterioro de su existencia. Esto se hace patente, precisamente, con la existencia de esta humanidad debilitada y asediada por la aflicción. Ese pasado de fortaleza sublimado; ese tiempo anterior sin duda idealizado de gente sana, robusta y longeva, subyace tan sólo hoy como "una leve visión" para tomar impulso hacia algo más excelente en que, como supermanes modernos, logren apropiarse de la modernidad "sin margen de error".

${ }^{50}$ Este extracto es un compendio de los calqueos de los días 6, 13 y 20 de abril de 2011 referidos al "vestido incorruptible", y del calqueo del 21 de diciembre de 2011, "El último año del conteo". He modificado la grafía para su mejor comprensión. 


\section{Bibliografía}

Aguirre Beltrán, Gonzalo

1967 Regiones de refugio, Instituto Indigenista Interamericano, México.

Balandier, Georges

1955 Sociologie actuelle de l'Afrique noire, Presses Universitaires de France (PUF), París.

Barabas, Alicia

1987 Utopías indias. Movimientos sociorreligiosos en México, Grijalbo, México.

2008 "Milenarismo y profecía en la etnogénesis de los macehualob de Quintana Roo, México", en Andrés Medina y Ángela Ochoa (dirs.), Etnografía de los confines, Centro de Estudios Mexicanos y Centroamericanos (CEMCA)/ Instituto Nacional de Antropología e Historia (INAH)/Universidad Nacional Autónoma de México (UNAM), México, pp. 163-178.

Bastide, Roger

1975 Le sacré sauvage, Payot, París.

Burridge, Kenelm

1969 New Heaven, New Earth: A Study of Millenarian Activities, London School of Economics and Political Science, Londres.

Cancian, Frank

1992 The Decline of Community in Zinacantan. Economy, Public Life, and Social Stratification, 1960-1987, Stanford University Press, Stanford.

Cohn, Norman

1981 En pos del milenio, Alianza Universidad, Madrid [1957].

Collier, George

1995 "La reestructuración de la etnicidad en Chiapas y en el mundo", en June Nash y Alejandro Parellada (comps.), La explosión de comunidades en Chiapas, Grupo Internacional de Trabajo sobre Asuntos Indígenas, Copenhague, pp. 7-19.

Collier, George y Daniel Mountjoy

1988 Adaptándose a la crisis de los ochenta: cambios socioeconómicos en Apas, Zinacantán, Instituto de Asesoría Antropológica para la Región Maya (Inaremac), San Cristóbal de Las Casas.

Collier, George et al.

2000 "Socio-Economic Change and Emotional Illness among the Highland Maya of Chiapas, Mexico", en Ethos, vol. 28, núm. 1, pp. 20-53.

Desroche, Henri

1973 Sociologie de l'espérance, Calmann-Lévy, París. 
Farriss, Nancy

1985 "Recordando el futuro, anticipando el pasado: tiempo histórico y tiempo cósmico entre los mayas de Yucatán”, en La memoria y el olvido: Segundo Simposio de Historia de las Mentalidades, INAH, México, pp. 47-60.

Fukuyama, Francis

1999 La gran ruptura, Atlántida, Buenos Aires.

Gossen, Gary H.

1989 "El tiempo cíclico en San Juan Chamula: ¿mistificación o mitología viva?", en Mesoamérica, núm. 18, diciembre, pp. 441-459.

2002 Four Creations: An Epic Story of the Chiapas Mayas, University of Oklahoma Press, Norman.

Groark, Kevin Patrick

2005 Pathogenic Emotions: Sentiment, Sociality, and Sickness among the Tzotzil Maya of San Juan Chamula, Chiapas, Mexico, Universidad de California, Los Ángeles.

Gutiérrez Estévez, Manuel

1988 "Lógica social en la mitología maya-yucateca: la leyenda del enano de Uxmal”, en Manuel Gutiérrez Estévez (comp.), Mito y ritual en América, Alhambra, Madrid, pp. 60-110.

1992 "Alteridad étnica y conciencia moral. El juicio final de los mayas yucatecos", en Jorge Klor de Alba et al. (eds.), De palabra y obra en el nuevo mundo, vol. II, Encuentros interétnicos, Siglo XXI de España Editores, Madrid, pp. 295-322. Jolom Mayaetik

2011 "Cómo fueron nuestras costumbres", en Jolom Mayaetik, 13 de mayo <http:// cooperativajolom.blogspot.com.es/2011/05/como-fueron-nuestrascostumbres.html $>$ [24 de agosto de 2013].

Lanternari, Vittorio

1962 Les mouvements religieux des peuples opprimés, Maspero, París.

León-Portilla, Miguel

1968 Tiempo y realidad en el pensamiento maya, UNAM, México. López García, Julián

2006 “Cuerpo y sociedad maya ch'orti'. Representaciones desde la sangre”, en Beatriz Muñoz González y Julián López García (eds.), Cuerpo y medicina. Textos y contextos culturales, Cicon Ediciones, Cáceres, pp. 385-407.

Neila Boyer, Isabel

2012a “Ach' kuxlejal (nuevo vivir). Amor, carácter y voluntad en la modernidad tzotzil”, en Pedro Pitarch Ramón y Gemma Orobitg (eds.), Modernidades indigenas, Iberoamericana/Vervuert, Madrid, pp. 279-317. 
2012b “Me' vinik. Una metáfora tzotzil sobre la salubridad de la vida en la modernidad de Los Altos de Chiapas", en Revista de Antropología Iberoamericana, vol. 7, núm. 2, pp. 137-170.

2013 "Ahora somos ya tan frágiles. Modernidad y trauma en la sociedad tzotzil contemporánea", en Revista de Antropología Iberoamericana (en dictamen).

Pereira de Queiroz, Maria Isaura

1977 O messianismo: No Brasil e no mundo, Alfa-Omega, São Paulo.

Pitarch, Pedro

2003 "Infidelidades indígenas", en Revista de Occidente, núm. 269, pp. 60-75.

Reifler Bricker, Victoria

1993 El cristo indígena, el rey nativo. El sustrato histórico de la mitología del ritual de los mayas, Fondo de Cultura Económica, México.

Robledo Hernández, Gabriela

1997 Disidencia y religión. Los expulsados de San Juan Chamula, Universidad Autónoma de Chiapas, Chiapas.

Robledo Hernández, Gabriela y Jorge Luis Cruz Burguete

2005 "Religión y dinámica familiar en Los Altos de Chiapas. La construcción de nuevas identidades de género", en Estudios Sociológicos, vol. XXIII, núm. 2, mayo-agosto, pp. 515-534.

Rus, Diana L.

1990 La crisis económica y la mujer indígena: El caso de Chamula, Chiapas, Inaremac, San Cristóbal de Las Casas.

Rus, Diana L.y Xalik Guzmán

1990 Bordando milpas. Un testimonio de María Gómez Pérez, una tejedora chamula de Los Altos de Chiapas, Inaremac, San Cristóbal de Las Casas.

Rus, Jan

1998 "La comunidad revolucionaria institucional: la subversión del gobierno indígena en Los Altos de Chiapas, 1936-1968”, en Juan Pedro Viqueira y Mario Humberto Ruz (eds.), Chiapas: los rumbos de otra historia, UNAM/ Centro de Investigaciones y Estudios Superiores en Antropología Social (CIESAS)/CEMCA/Universidad de Guadalajara, México, pp. 251-277.

Rus, Jan y George Collier

2002 "Una generación en crisis en los Altos de Chiapas: Los casos de Chamula y Zinacantán, 1974-2000”, en Shannan Mattiace, Rosalva Hernández Castillo y Jan Rus (eds.), Tierra, libertad y autonomía: impactos regionales del zapatismo en Chiapas, CIESAS, México, pp. 157-199.

Séguy, Jean

1983 "Sociologie de l'attente", en Charles Perrot (comp.), Le retour du Christ, PUF, París, pp. 71-102. 
Siverts, Henning

1971 "On Politics and Leadership in Highland Chiapas", en Evon Vogt y Alberto Ruz, Desarrollo cultural de los mayas, Centro de Estudios Mayas-UnAm, México, pp. 363-384.

Ullán de la Rosa, Francisco Javier

2002 "El fenómeno milenarista como revelador de crisis y conflictos sociales. El movimiento de Amalia Bautista entre los nahuas de la Huasteca veracruzana", en Estudios del Hombre, núm. 15, pp. 69-107.

Vinhas de Queiroz, Mauricio

1963 “'Cargo Cult' na Amazonia. Observaçoes sobre o milenarismo tekuna”, en América Latina, vol. 6, núm. 4, octubre-diciembre, pp. 43-61.

Wasserstrom, Robert

1980 Ingreso y trabajo rural en Los Altos de Chiapas, Centro de Investigaciones Ecológicas del Sureste/Inaremac, San Cristóbal de Las Casas.

Wolf, Eric

1957 "Closed Corporate Peasant Communities in Mesoamerica and Central Java”, en South-Western Journal of Anthropology, núm. 13, pp. 1-18.

1986 "The Vicisitudes of the Closed Corporate Peasant Community", en American Ethnologist, vol. 13, núm. 2, pp. 325-329.

Worsley, Peter

1980 Al son de la trompeta final. Un estudio de los cultos "cargo" en Melanesia, Siglo XXI de España Editores, Madrid [1957].

Isabel Neila Boyer

Candidata doctoral en Antropología Social y Cultural en la Universidad Nacional de Educación a Distancia (UNED), diplomada en Historia y Antropología de América y magister en Estudios Amerindios por la Universidad Complutense de Madrid; especialista en temas de Cooperación y Desarrollo y Género y Políticas de Igualdad por la UNED y la Universidad Rey Juan Carlos, respectivamente. Desde 2002 viene realizando trabajo de campo etnográfico en Perú, Brasil y México sobre violencias, antropología de las emociones, la modernidad y la ética amerindia. Entre sus más recientes publicaciones están: “Acb' Kuxlejal: El Nuevo Vivir. Amor, carácter y voluntad en la modernidad tzotzil”, en Modernidades indígenas (Iberoamericana/ Vervuert, 2012), "Me' Vinik. Una metáfora tzotzil sobre la salubridad de la vida en la modernidad de Los Altos de Chiapas", en aibr (2012) y "Los amores locos de una joven chamula. Simpatías materno filiales y cambio social en Chiapas", en EntreDiversidades (2013). 
Citar como: Isabel Neila Boyer (2013), "Supermanes modernos: utopía y crisis social en el nuevo vivir tzotzil en Chiapas, México", Iztapalapa. Revista de Ciencias Sociales y Humanidades, núm. 75, año 34, julio-diciembre de 2013, ISSN: 2007-9176; pp. 157-I97. Disponible en <http://revistaiztapalapa. izt.uam.mx/index.php/izt/issue/archive >. 